\title{
Methyl bromide: Ocean sources, ocean sinks, and climate sensitivity
}

\author{
A. D. Anbar ${ }^{1}$ and Y. L. Yung \\ Division of Geological and Planetary Sciences, California Institute of Technology, Pasadena \\ F. P. Chavez \\ Monterey Bay Aquarium Research Institute, Moss Landing, California
}

\begin{abstract}
The oceans play an important role in the geochemical cycle of methyl bromide $\left(\mathrm{CH}_{3} \mathrm{Br}\right)$, the major carrier of $\mathrm{O}_{3}$-destroying bromine to the stratosphere. The quantity of $\mathrm{CH}_{3} \mathrm{Br}$ produced annually in seawater is comparable to the amount entering the atmosphere each year from natural and anthropogenic sources. The production mechanism is unknown but may be biological. Most of this $\mathrm{CH}_{3} \mathrm{Br}$ is consumed in situ by hydrolysis or reaction with chloride. The size of the fraction which escapes to the atmosphere is poorly constrained; measurements in seawater and the atmosphere have been used to justify both a large oceanic $\mathrm{CH}_{3} \mathrm{Br}$ flux to the atmosphere and a small net ocean sink. Since the consumption reactions are extremely temperature-sensitive, small temperature variations have large effects on the $\mathrm{CH}_{3} \mathrm{Br}$ concentration in seawater, and therefore on the exchange between the atmosphere and the ocean. The net $\mathrm{CH}_{3} \mathrm{Br}$ flux is also sensitive to variations in the rate of $\mathrm{CH}_{3} \mathrm{Br}$ production. We have quantified these effects using a simple steady state mass balance model. When $\mathrm{CH}_{3} \mathrm{Br}$ production rates are linearly scaled with seawater chlorophyll content, this model reproduces the latitudinal variations in marine $\mathrm{CH}_{3} \mathrm{Br}$ concentrations observed in the east Pacific Ocean by Singh et al. [1983] and by Lobert et al. [1995]. The apparent correlation of $\mathrm{CH}_{3} \mathrm{Br}$ production with primary production explains the discrepancies between the two observational studies, strengthening recent suggestions that the open ocean is a small net sink for atmospheric $\mathrm{CH}_{3} \mathrm{Br}$, rather than a large net source. The Southern Ocean is implicated as a possible large net source of $\mathrm{CH}_{3} \mathrm{Br}$ to the atmosphere. Since our model indicates that both the direction and magnitude of $\mathrm{CH}_{3} \mathrm{Br}$ exchange between the atmosphere and ocean are extremely sensitive to temperature and marine productivity, and since the rate of $\mathrm{CH}_{3} \mathrm{Br}$ production in the oceans is comparable to the rate at which this compound is introduced to the atmosphere, even small perturbations to temperature or productivity can modify atmospheric $\mathrm{CH}_{3} \mathrm{Br}$. Therefore atmospheric $\mathrm{CH}_{3} \mathrm{Br}$ should be sensitive to climate conditions. Our modeling indicates that climate-induced $\mathrm{CH}_{3} \mathrm{Br}$ variations can be larger than those resulting from small $( \pm 25 \%)$ changes in the anthropogenic source, assuming that this source comprises less than half of all inputs. Future measurements of marine $\mathrm{CH}_{3} \mathrm{Br}$, temperature, and primary production should be combined with such models to determine the relationship between marine biological activity and $\mathrm{CH}_{3} \mathrm{Br}$ production. Better understanding of the biological term is especially important to assess the importance of non anthropogenic sources to stratospheric ozone loss and the sensitivity of these sources to global climate change.
\end{abstract}

\section{Introduction}

The observation that bromine plays a significant role in the depletion of polar ozone [McElroy et al., 1986; Salawitch et al., 1988; Anderson et al., 1989] has stimulated interest in the

${ }^{1}$ Now at the Department of Earth and Environmental Science and the Department of Chemistry, University of Rochester, Rochester, New York.

Copyright 1996 by the American Geophysical Union.

Paper number 95GB02743.

0886-6236/96/95GB-02743\$10.00 importance of bromine compounds in the destruction of stratospheric ozone at midlatitudes [World Meteorological Organization (WMO), 1992], a possibility first noted in the 1970s [Wofsy et al., 1975]. As much as a third of Antarctic ozone loss is believed to be due to bromine, which implies that a bromine atom is $\approx 50$ times as efficient as a chlorine atom in destroying $\mathrm{O}_{3}$ [Wofsy et al., 1975; Salawitch et al., 1988; Solomon et al., 1992]. In the midlatitude lower stratosphere, recent data indicate that bromine accounts for $\approx 15 \%$ of total ozone loss [Wennberg et al., 1994]. Methyl bromide $\left(\mathrm{CH}_{3} \mathrm{Br}\right)$ is of special importance because it is the major carrier of bromine to the stratosphere [Wofsy et al., 
1975; Yung et al., 1980; Schauffler et al., 1993], and because the magnitudes of the natural and anthropogenic sources of $\mathrm{CH}_{3} \mathrm{Br}$ may be comparable [Singh et al., 1983; WMO, 1992; Khalil et al., 1993; Reeves and Penkett, 1993; Singh and Kanakidou, 1993]. However, since the lifetime of $\mathrm{CH}_{3} \mathrm{Br}$ with respect to atmospheric loss processes is only $\approx 1.7$ years [Mellouki et al., 1992], its emissions are not limited by existing international agreements on anthropogenic halocarbons, which were intended to minimize long-term ozone loss. As a result, $\mathrm{CH}_{3} \mathrm{Br}$ has only recently become a focus of both regulatory and scientific attention [WMO, 1992].

The fate of $\mathrm{CH}_{3} \mathrm{Br}$ in the atmosphere, where the most likely sink is a reaction with $\mathrm{OH}$ radical, has been well studied. Measurements of $\mathrm{CH}_{3} \mathrm{Br}$ have been combined with one-dimensional and two-dimensional gas phase kinetic models to estimate the rate of destruction in the atmosphere [Wofsy et al., 1975; Yung et al., 1980; Reeves and Penkett, 1993], which in turn can be used to constrain the flux of $\mathrm{CH}_{3} \mathrm{Br}$ to the atmosphere under steady state conditions. These studies converge on a total source strength of 0.8 to 1.0

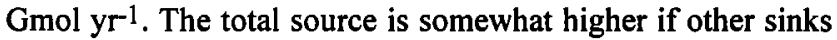
are considered (e.g., $0.9-1.2 \mathrm{Gmol} \mathrm{yr}^{-1}$; Lobert et al., [1995]). The goal of most current methyl bromide research is to determine the relative magnitudes of various natural and anthropogenic sources, about which there are large uncertainties. These include industrial and agricultural sources of $\mathrm{CH}_{3} \mathrm{Br}$, biogenic emissions (such as from marine organisms), and pyrogenic $\mathrm{CH}_{3} \mathrm{Br}$ from biomass burning.

Characterization of methyl bromide in the marine environment is particularly important, since the oceanic flux is a critical unknown in the $\mathrm{CH}_{3} \mathrm{Br}$ atmospheric budget. While the first observational studies suggested that the ocean is a large net source of $\mathrm{CH}_{3} \mathrm{Br}$ [Singh et al., 1983; Khalil et al., 1993], more recent work indicates a small net sink [Lobert et al., 1995]. Constraining the oceanic flux is critical to a rational regulatory approach to industrial use of $\mathrm{CH}_{3} \mathrm{Br}$, since it is necessary to know how the size of the anthropogenic source compares to natural sources. Additionally, the magnitude of the gross flux of $\mathrm{CH}_{3} \mathrm{Br}$ into the ocean affects the atmospheric lifetime of $\mathrm{CH}_{3} \mathrm{Br}$ and, hence the ozone depletion potential (ODP) of this compound [Mellouki et al., 1992; Lobert et al., 1995]. Finally, the variability of the oceanic flux in response to the changing atmospheric burden of $\mathrm{CH}_{3} \mathrm{Br}$ may "buffer" atmospheric $\mathrm{CH}_{3} \mathrm{Br}$ against changes in the magnitude of anthropogenic sources [Butler, 1994].

The conflicting conclusions of the observational studies of marine methyl bromide arise primarily from differences in the observed concentrations of $\mathrm{CH}_{3} \mathrm{Br}$ in seawater and from the assumptions used to extrapolate measurements made in limited geographic areas to the global oceans. Below, using a simple, steady state model, we reexamine the data of Singh et al. [1983] ("Cruise $A$ ") and Lobert et al. [1995] ("Cruise B") to evaluate the hypothesis of a large ocean source. When we carefully consider the marine chemistry of $\mathrm{CH}_{3} \mathrm{Br}$, substantial spatial and temporal variations in the seawater concentration and oceanic flux appear inevitable because of the temperature sensitivity of $\mathrm{CH}_{3} \mathrm{Br}$ inorganic chemistry and because of the apparent role of biological activity in $\mathrm{CH}_{3} \mathrm{Br}$ production.
These effects can be modeled with some confidence and account for most of the observational discrepancies. We find that the data of Singh et al. [1983] are consistent with the small ocean sink determined by Lobert et al. [1995], when these data are reinterpreted. Since marine temperature and productivity are both functions of climate, the possible effects of climate change on atmospheric $\mathrm{CH}_{3} \mathrm{Br}$ are also explored, using a coupled ocean-atmosphere model.

\section{Marine Chemistry of $\mathrm{CH}_{3} \mathrm{Br}$}

All studies of methyl bromide in seawater reveal concentrations too high to be the simple result of invasion from the atmosphere balanced in steady state against the known marine loss processes, indicating a large rate of $\mathrm{CH}_{3} \mathrm{Br}$ production in the water column [e.g., Singh et al., 1983; Khalil et al., 1993; Lobert et al., 1995]. This production process is poorly understood, although it has been assumed to be biological in the absence of other explanations [e.g., Singh and Kanakidou, 1993], and because biogenesis of halogenated organics in natural waters is well known [e.g., Gschwend et al., 1985; Manley and Dastoor, 1986; Moore and Tokarczyk, 1993; Itoh and Shinya, 1994]. Production of $\mathrm{CH}_{3} \mathrm{Br}$ by marine kelp and phytoplankton has been observed, although not at rates sufficient to support the observed seawater concentrations [Manley and Dastoor, 1986; Moore et al., 1995]. Quantitative identification of the $\mathrm{CH}_{3} \mathrm{Br}$ production mechanism is of obvious importance.

$\mathrm{CH}_{3} \mathrm{Br}$ is also consumed in the ocean, by nucleophilic substitution by $\mathrm{Cl}^{-}$and by hydrolysis [Zafiriou, 1975; Elliott and Rowland, 1993]:

$$
\begin{aligned}
\mathrm{CH}_{3} \mathrm{Br}+\mathrm{Cl}^{-} & \rightarrow \mathrm{CH}_{3} \mathrm{Cl}+\mathrm{Br}^{-} \\
\mathrm{CH}_{3} \mathrm{Br}+\mathrm{H}_{2} \mathrm{O} & \rightarrow \mathrm{CH}_{3} \mathrm{OH}+\mathrm{H}^{+}+\mathrm{Br}^{-}
\end{aligned}
$$

Using available kinetic data [Moelwyn-Hughes, 1938; Moelwyn-Hughes, 1953; Bathgate and Moelwyn-Hughes, 1959; Mabey and Mill, 1978; Elliott and Rowland, 1993], the rate constants for these reactions are $k_{\mathrm{Cl}}=9.5 \times 10^{12} \mathrm{e}(-2679 / T)$ liters $\mathrm{mol}^{-1} \mathrm{~s}^{-1}$ and $k_{\mathrm{H}_{2} \mathrm{O}}=1.0 \times 10^{12} \mathrm{e}^{(-13348 / T)} \mathrm{s}^{-1}$. At a typical open ocean surface temperature of $21.9^{\circ} \mathrm{C}$ [Lobert et al., 1995], and $\left[\mathrm{Cl}^{-}\right]=0.56 \mathrm{~mol} \mathrm{liter}^{-1}$, the pseudo first-order rate constant for $\mathrm{CH}_{3} \mathrm{Br}$ loss can be estimated as $\approx 10^{-6} \mathrm{~s}^{-1}$. This value is comparable to the air-sea exchange constant estimated for methyl halides [Liss and Slater, 1974; Zafiriou, 1975]. A priori, this suggests that the rate of $\mathrm{CH}_{3} \mathrm{Br}$ destruction in the water column should be of comparable magnitude to the escape flux to the atmosphere. This is an important point: Assuming steady state in the upper oceans, the net flux between the atmosphere and ocean $\left(F_{n e t}\right)$ must equal the difference between the rate of $\mathrm{CH}_{3} \mathrm{Br}$ production $\left(P_{o}\right)$ and the rate at which $\mathrm{CH}_{3} \mathrm{Br}$ is destroyed in the water column $\left(D_{o}\right)$, that is, $F_{n e t}=P_{o}-D_{o}$. If $D_{o}$ is as large as, or larger than, $F_{n e t}$ then moderate perturbations to either $P_{o}$ or $D_{o}$ will have a nontrivial impact on $F_{n e t}$. This can impact atmospheric $\mathrm{CH}_{3} \mathrm{Br}$.

The magnitudes of $P_{o}, D_{o}$, and $F_{n e t}$ on a global average basis have been constrained using measurements of $\mathrm{CH}_{3} \mathrm{Br}$ in the atmosphere and ocean. Determinations of tropospheric $\mathrm{CH}_{3} \mathrm{Br}$ all converge on a global average abundance of $\approx 10$ ppt [Singh et al., 1983; Penkett et al., 1985; Cicerone et al., 
1988; Atlas et al., 1993; Khalil et al., 1993; Singh and Kanakidou, 1993; Lal et al., 1994; Lobert et al., 1995]. A decreasing concentration gradient from the northern to southern hemisphere is typically observed, possibly due to higher anthropogenic emissions in the north [Reeves and Penkett, 1993]. A slight global increase was reported from 1983 to 1991 , possibly due to increasing anthropogenic use over this time, and uncorrelated short-term variations of less than $\approx 2$ ppt have been reported at various latitudes [Khalil et al., 1993]. However, observations of variations in atmospheric $\mathrm{CH}_{3} \mathrm{Br}$ concentrations through time are complicated by analytical artifacts [Montzka et al., 1995].

Although few measurements have been made, $\mathrm{CH}_{3} \mathrm{Br}$ in seawater $\left(c_{o}\right)$ is apparently more variable, reflecting the $\approx 10$-day residence time with respect to chemical loss. Singh et al. [1983] (recalibrated by Singh and Kanakidou [1993]) determined an average value of $\approx 5.2 \times 10^{-9} \mathrm{~mol} \mathrm{~m}^{-3}$ in the near-shore eastern Pacific, with site-to-site variations as large as a factor of 6 (Cruise $A$ ). Lobert et al. [1995], following a ship track $10^{\circ}-20^{\circ}$ further west, found substantially lower concentrations, ranging from $\approx 1$ to $2.5 \times 10^{-9} \mathrm{~mol} \mathrm{~m}^{-3}$ (Cruise B). Khalil et al. [1993] observed an average value intermediate between these two across a larger area of the Pacific, as well as a trend of $\mathrm{CH}_{3} \mathrm{Br}$ increasing by a factor of 2 in seawater from southern to northern latitudes.

When combined with the atmospheric data, these marine data sets have been used to justify a wide range of $F_{\text {net }}$ estimates. Singh et al. [1983] originally determined a global

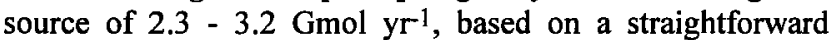
extrapolation of observations of $\mathrm{CH}_{3} \mathrm{Br}$ supersaturation in the eastern Pacific. If correct, such values require the existence of a large, unidentified sink for atmospheric $\mathrm{CH}_{3} \mathrm{Br}$. In a recent reevaluation of these data, Singh and Kanakidou [1993] assumed that the magnitude of the $\mathrm{CH}_{3} \mathrm{Br}$ flux is proportional to marine primary production, and/or to the $\mathrm{CH}_{3} \mathrm{Cl}$ flux, and thereby estimated a global source of 0.42 $0.84 \mathrm{Gmol}^{\mathrm{yr}}{ }^{-1}$. This approaches the findings of Khalil et al. [1993], who estimated a source of $0.32-0.42 \mathrm{Gmol} \mathrm{yr}^{-1}$ based on a more geographically representative sampling of Pacific Ocean waters. However, it is not apparent why the $\mathrm{CH}_{3} \mathrm{Br}$ flux should be proportional to primary production, even if biological sources dominate. Since the flux is a function of the difference between $\mathrm{CH}_{3} \mathrm{Br}$ production and loss $\left(F_{n e t}=P_{o}-D_{o}\right)$, proportionality will only occur if the loss rate is negligibly small $\left(F_{n e t} \approx P_{o}\right.$ ), or if the rate of $\mathrm{CH}_{3} \mathrm{Br}$ loss is directly proportional to the rate of production, with a proportionality constant that is insensitive to temperature or other variables $\left(F_{\text {net }}=P_{o}-a P_{o} ; a=\right.$ constant $)$. Neither assumption is justified a priori. As for the correlation between the fluxes of $\mathrm{CH}_{3} \mathrm{Br}$ and $\mathrm{CH}_{3} \mathrm{Cl}$, this does not appear to be a consistent relationship [e.g., Lobert et al., 1995].

More recently, Lobert et al. [1995] estimated a net $\mathrm{CH}_{3} \mathrm{Br}$

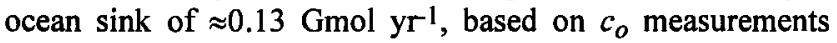
lower than those observed previously, as well as on a more realistic extrapolation to the global oceans. The reason(s) for the lower measured $\mathrm{CH}_{3} \mathrm{Br}$ concentrations has not been explained in the literature, although it has been suggested that analytical artifacts led to erroneously high seawater measurements in the previous studies [Lobert et al., 1995].

Despite the divergence of $F_{\text {net }}$ estimates, as well as a variety of other uncertainties in making global extrapolations (e.g., average seawater temperature), all studies indicate that most of the $\mathrm{CH}_{3} \mathrm{Br}$ produced in the oceans is consumed in the oceans. For example, Singh and Kanakidou [1993] estimate $F_{\text {net }} \approx 0.42-0.84 \mathrm{Gmol} \mathrm{yr}^{-1}$, against a total marine production rate of $2.1-3.2 \mathrm{Gmol} \mathrm{yr}^{-1}$, and losses of $1.7-2.4 \mathrm{Gmol} \mathrm{yr}^{-1}$. The data of Lobert et al. [1995] extrapolate to $F_{\text {net }} \approx-0.13$ $\mathrm{Gmol} \mathrm{yr} r^{-1}, D_{o} \approx 1.7 \mathrm{Gmol} \mathrm{yr}^{-1}$, and $P_{o} \approx 1.6 \mathrm{Gmol} \mathrm{yr}^{-1}$ for the global ocean. Thus $F_{\text {net }}$ accounts for at most $\approx 40 \%$ of the $\mathrm{CH}_{3} \mathrm{Br}$ production in the ocean, and it is possible that all the $\mathrm{CH}_{3} \mathrm{Br}$ produced in seawater is consumed in situ. As a result, $c_{o}$ and $F_{\text {net }}$ should be quite sensitive to perturbations of the rates of $D_{o}$ and $P_{o}$, as suggested above. The response time to such changes is on the order of weeks, reflecting the short residence time of $\mathrm{CH}_{3} \mathrm{Br}$ in seawater. Therefore variations of $c_{o}$ should be readily apparent if such perturbations exist. Since measurements of $c_{o}$ reveal substantial, unexplained variations with depth and location [Singh et al., 1983; Khalil et al., 1993; Lobert et al., 1995], it appears that the rates of $\mathrm{CH}_{3} \mathrm{Br}$ production and/or chemical loss are, indeed, highly variable.

We suggest that substantial variability in the rate of $\mathrm{CH}_{3} \mathrm{Br}$ consumption arises from the extreme temperature-dependence of the rates of hydrolysis and the reaction with chloride; the Arrhenius activation energies, $E_{a}$, are $\approx 100 \mathrm{~kJ} / \mathrm{mol}$, leading to an increase in the rate constants of nearly an order of magnitude as temperature is raised from $0^{\circ} \mathrm{C}$ to $22^{\circ} \mathrm{C}$ (Figure 1). The potential impact of this effect in seawater is shown in Figure $2 \mathrm{a}$, where the combined rate constant for loss by hydrolysis and displacement by $\mathrm{Cl}^{-}$has been calculated using measured sea surface temperatures (SSTs) as a function of latitude for Cruise $A$ and Cruise $B$ [Singh et al., 1983; Lobert et al., 1995]. Along these transects the potential for $\mathrm{CH}_{3} \mathrm{Br}$ destruction at low northern latitudes, where temperatures are highest, is as much as 4 -times that at $30^{\circ} \mathrm{S}$. Thus substantial variations in the exchange of $\mathrm{CH}_{3} \mathrm{Br}$ between the atmosphere and ocean should arise from naturally occurring temperature changes, such as those associated with latitudinal variations, seasonal cycles, and global climate change.

Variations in the rate of production of $\mathrm{CH}_{3} \mathrm{Br}$, which could also lead to substantial variability in marine and atmospheric $\mathrm{CH}_{3} \mathrm{Br}$ levels, are more difficult to quantify, largely because the $\mathrm{CH}_{3} \mathrm{Br}$ in situ source has not yet been identified. Below, we explore the possibility that $\mathrm{CH}_{3} \mathrm{Br}$ production is a function of primary production in the oceans [Singh and Kanakidou, 1993]. To do this, we scale $\mathrm{CH}_{3} \mathrm{Br}$ production rates to observed marine chlorophyll abundances (primary production and chlorophyll abundance are proportional under conditions of constant illumination, e.g., Morel and Berthon, [1989]). Chlorophyll data are available from shipboard measurements (in vivo fluorescence or extracted chlorophyll), and from satellite observations of ocean color. Measurements from the coastal zone color scanner (CZCS) experiment on the Nimbus 7 satellite for the month of December (climatological average from $1979-1986$ ), the month of Cruise $A$, are presented in Figure 2b [Feldman, 1989]. Gaps in this data set along the shiptrack are minimal and were filled by linear extrapolation from adjacent pixels. Continuous measurements of in vivo phytoplankton fluorescence, a surrogate for chlorophyll concentration [Lorenzen, 1966], were made during the cruise 


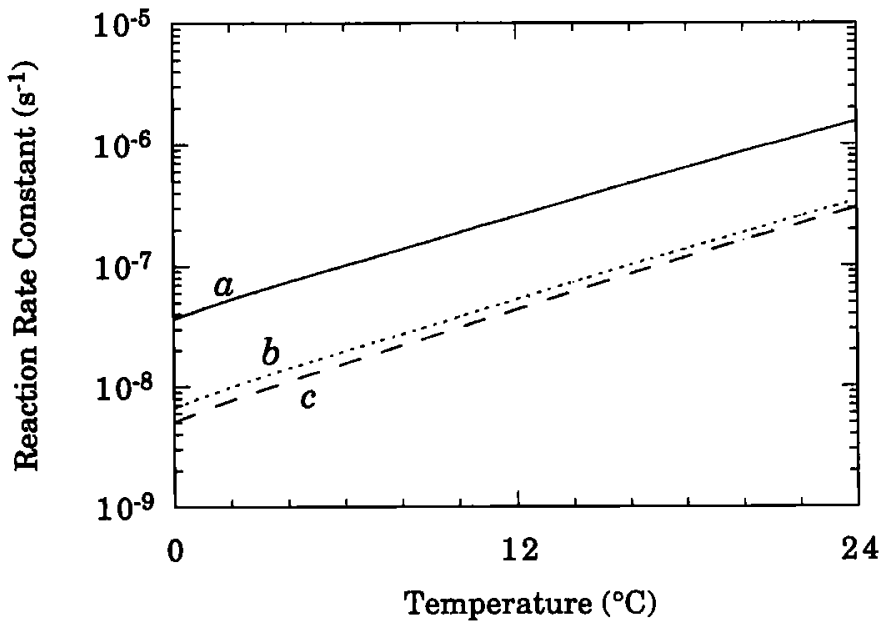

Figure 1. The temperature sensitivity of the rate constants important for $\mathrm{CH}_{3} \mathrm{Br}$ loss in seawater: (a) $\mathrm{CH}_{3} \mathrm{Br}+\mathrm{Cl}^{-}$, (b) and (c) $\mathrm{CH}_{3} \mathrm{Br}+\mathrm{H}_{2} \mathrm{O}$, expressed as pseudo first-order constants for marine conditions $\left(\left[\mathrm{Cl}^{-}\right]=0.56 \mathrm{~mol}^{\text {liter }}{ }^{-1}\right.$. References: (a) Elliott and Rowland [1993]; (b) Mabey and Mill [1978]; (c) Moelwyn-Hughes [1938].

of Lobert et al. [1995] in January - February of 1994 (Cruise $B)$. These data are also presented in Figure $2 \mathrm{~b}$. These observations indicate that during Cruise $A$, production rates near $10^{\circ} \mathrm{S}$ along the shiptrack were more than twice the regional average, while productivity near $25^{\circ} \mathrm{S}$ was particularly low. Chlorophyll variations during Cruise $B$ were much more subdued. This reflects that the later cruise sampled waters more representative of the open ocean, where productivity is uniformly low relative to coastal waters. Clearly, if $\mathrm{CH}_{3} \mathrm{Br}$ production correlates with primary production, substantial latitudinal and longitudinal variations in $\mathrm{CH}_{3} \mathrm{Br}$ abundances and ocean-atmosphere exchange should result from this effect, as well as from temperature.

\section{Marine $\mathrm{CH}_{3} \mathrm{Br}$ : A Steady State Ocean Model}

\section{General Model Description}

Since the residence time of $\mathrm{CH}_{3} \mathrm{Br}$ in the oceans is much less than the atmospheric residence time, we can quantify the short-term response of $c_{o}$ to ocean temperature variations by assuming a constant value of $\mathrm{CH}_{3} \mathrm{Br}$ in the atmosphere and by considering a simple steady state model of the upper ocean. In this system the rate of biological $\mathrm{CH}_{3} \mathrm{Br}$ production per unit area $(P)$ is balanced by chemical loss in the mixed layer, by removal by eddy mixing to, and by chemical loss in deeper waters, and also by escape to the atmosphere:

$$
\begin{gathered}
\frac{d c_{o}}{d t}=\frac{P}{z}-k_{d}(T) c_{o}-\frac{\left(k_{d}\left(T_{t h}\right) D_{z}\right)^{1 / 2}}{z} c_{o} \\
-\frac{K_{l} \times 10^{-12}}{z H(T)}\left(\frac{H(T)}{10^{-12}} c_{o}-p_{a}\right)
\end{gathered}
$$

where $k_{d}(T)$ is the temperature-dependent rate constant for chemical loss $\left(k_{d}(T)=k_{\mathrm{Cl}}(T)+k_{\mathrm{H}_{2} \mathrm{O}}(T)\right) . \quad D_{z}\left(5.4 \times 10^{3} \mathrm{~m}^{2}\right.$ $\mathrm{yr}^{-1}$ ) parameterizes the rate of vertical mixing from the mixed layer down to a thermocline of average temperature $T_{t h}$, where $\mathrm{CH}_{3} \mathrm{Br}$ undergoes chemical loss [Butler et al., 1991; Butler, 1994]; $K_{l}$ is the air-sea exchange coefficient expressed on a liquid phase basis $\left(1.2 \times 10^{3} \mathrm{~m} \mathrm{yr}^{-1}\right.$, calculated by the method of Liss and Slater [1974]). $H(T)$ is the Henry's law

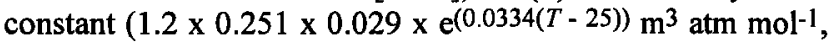
where $0.251=H\left(25^{\circ} \mathrm{C}\right)$ in pure water, 1.2 accounts for the salting-out effect in seawater, and 0.029 converts from the unitless partition coefficient to the units used here [Singh et al., 1983]. Here $c_{o}$ is the concentration of $\mathrm{CH}_{3} \mathrm{Br}$ in the ocean (mole per cubic meter). Also $p_{a}$ is the partial pressure of $\mathrm{CH}_{3} \mathrm{Br}$ in the atmosphere (parts per trillion) and the factor of $10^{-12}$ converts units between parts per trillion and atmosphere.

Solving for $c_{o}$ at steady state, we obtain:

$$
c_{o}=\left[P+\frac{K_{l} p_{a} \times 10^{-12}}{H(T)}\right] \times\left[\frac{1}{z k_{o}(T)+K_{l}}\right]
$$

where:

$$
k_{o}(T)=k_{d}(T)+\frac{\left(k_{d}\left(T_{t h}\right) D_{z}\right)^{1 / 2}}{z}
$$

We have used (2) to examine the effect of $T$ and $P$ on $c_{o}$ along the shiptracks of Cruise $A$ [Singh et al., 1983; Singh and Kanakidou, 1993] and Cruise $B$ [Lobert et al., 1995]. The data of Khalil et al. [1993] are not considered because chlorophyll data, used below to model variations of $P$, are not available for this shiptrack.

\section{Constant Production Model: Results and Comparison with Observations}

Initially, we assume a uniform value of $P$ across the sampled waters $\left(P_{\text {avg }}\right)$. Although this is unlikely to be a valid assumption (Figure $2 b$ ), it allows us to isolate the effects of temperature, since any latitudinal variations in the calculated $c_{o}$ will arise exclusively from the effect of temperature on $k_{d}$. Productivity effects are considered in the next section. $P_{\text {avg }}$ for each cruise was determined by expressing (2) to solve for $P$ in terms of measured values of $c_{o}$ and $T$ at each point along the shiptrack, and then averaging these $P$ values (Cruise $A$ : $P_{\text {avg }}=1.5 \times 10^{-14} \mathrm{Gmol} \mathrm{m}^{-2} \mathrm{yr}^{-1}$; Cruise $B: P_{\text {avg }}=3.8 \times 10^{-15}$ Gmol m$~_{-2} \mathrm{yr}^{-1}$ ). Here $p_{a}$ is fixed at 11 and $8.5 \mathrm{ppt}$ in the northern and southern hemispheres, respectively. A mixed layer depth of $30 \mathrm{~m}$ is assumed for Cruise $A$, and $75 \mathrm{~m}$ for Cruise $B$. The temperature in the mixed layer is considered equal to the measured SST, falling to an average thermocline value of $15^{\circ} \mathrm{C}$. These parameters are consistent with oceanographic data from the sampled regions [S. Pazan, personal communication, Lobert et al., 1995].

Some averaging of the obervational data is necessary to smooth over the effects of horizontal circulation, which can be significant during the lifetime of $\mathrm{CH}_{3} \mathrm{Br}$ in seawater. Data used in the models (e.g., temperature, chlorophyll abundance) were averaged at the indicated resolution prior to calculation. In the case of Cruise $B, 1^{\circ}$ latitudinal bins were chosen. Bins of $10^{\circ}$ width were employed in the case of Cruise $A$ due to the courseness of the $\mathrm{CH}_{3} \mathrm{Br}$ observations to which model results 

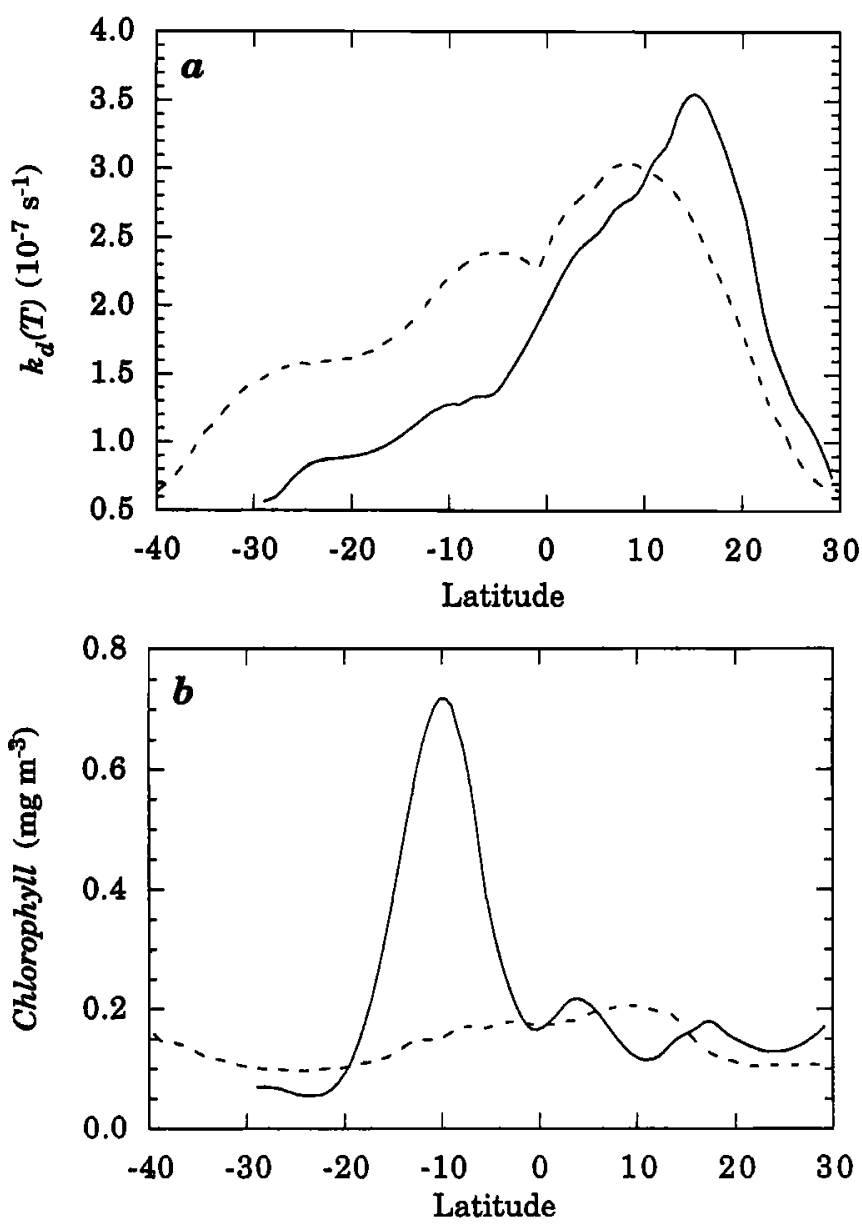

Figure 2. Latitudinal variability of (a) the rate of $\mathrm{CH}_{3} \mathrm{Br}$ destruction $\left(k_{d}(T)=k_{\mathrm{Cl}}(T)+k_{\mathrm{H}_{2} \mathrm{O}}(T)\right)$, and (b) the abundance of chlorophyll (milligrams per cubic meter), along the shiptracks of Singh et al. [1983] (Cruise $A$; solid lines) and Lobert et al. [1995] (Cruise $B$; dashed lines). Here $k_{d}(T)$ was calculated using the rate constants in Figure 1, and temperature from SST measurements during the cruises. Chlorophyll data for Cruise $A$ are drawn from CZCS observations, as described in the text [Feldman, 1989]. Cruise $B$ chlorophyll data are based on shipboard fluorescence measurements made during the cruise [Chavez, 1995].

were compared. Data collected from $16^{\circ} \mathrm{S}$ to $10^{\circ} \mathrm{S}$ during Cruise $A$, as well as those from Cruise $B$ north of $30^{\circ} \mathrm{N}$ and south of $40^{\circ} \mathrm{S}$, were omitted to exclude anthropogenic and/or near shore effects. For Cruise $A$, the data of Singh et al. [1983] were divided by a factor of 2.3, following the recalibration of Singh and Kanakidou [1993].

The results of this constant production model are a reasonable qualitative and quantitative fit to the Cruise $A$ observations from $10^{\circ} \mathrm{S}$ to $30^{\circ} \mathrm{N}$, which exhibit $c_{o}$ variations of nearly a factor of 2 (Figure $3 \mathrm{a}$ ). Model predictions and observations agree to within $\approx 30 \%$ in this region. Notably, the model reproduces the observed minimum in the low-latitude northern hemisphere, a reflection of the SST maximum in this region (Figure 2a). The discrepancies between the model results and observations are greatest at the southern latitudes, where the model deviates from observations by as much as $115 \%$. This is likely due to a flaw in the assumption that
$\mathrm{CH}_{3} \mathrm{Br}$ production rates are uniform across the sampled waters, a particularly implausible assumption for southern waters in which chlorophyll abundances are typically low during December (Figure 2b).

The model results for Cruise $B$ are a markedly better fit to the observational data (Figure $3 \mathrm{~b}$ ). Most points agree to well within $30 \%$ (the average deviation is $25 \%$ ), and the general trend of increasing concentrations at higher latitudes is reproduced. This good agreement presumably results from the fact that this cruise sampled waters more representative of the open oceans, where productivity is low and relatively uniform (Figure 2b). Temperature should be the dominant control on $\mathrm{CH}_{3} \mathrm{Br}$ concentrations in such waters.

\section{Variable Production Model: Results and Comparison with Observations}

The variability in $\mathrm{CH}_{3} \mathrm{Br}$ production rates can be easily parameterized by scaling the $\mathrm{CH}_{3} \mathrm{Br}$ production rate to chlorophyll concentration, assuming a linear correlation exists between these variables. Heretofore this was an unproven assumption. However, its validity is demonstrated by the highly linear relationship seen when regressing $C h l$ against $P_{\text {model }}$ (Figure 4a), where $P_{\text {model }}$ is obtained by substituting observed $c_{o}$ and $T$ into (2), to calculate a model $P$ at each latitude. When using the Cruise $B$ data, the correlation coefficient, $r$, is $\mathbf{0 . 8 2}$. Thus it is reasonable to conclude that chlorophyll concentration and $\mathrm{CH}_{3} \mathrm{Br}$ production rates are strongly correlated and, in turn, that $\mathrm{CH}_{3} \mathrm{Br}$ production and primary production are related. We note that the correlation coefficient increases to $>0.90$ if these data are averaged to $10^{\circ}$ latitudinal resolution, suggesting that mixing effects may still be significant at $1^{\circ}$ resolution.

A similar analysis using Cruise $A$ data also shows a generally linear trend (Figure $4 a$ ), but with noticeably poorer correlation ( $r=0.66$ ), slightly different slope, and a much larger intercept. Analytical artifacts in the $\mathrm{CH}_{3} \mathrm{Br}$ data from Cruise $A$ may account for some of the scatter [Montzka et al., 1995]. Additionally, discrepancies arise from at least two problems with the satellite-based ocean color observations used to derive $C h l$ along the Cruise $A$ shiptrack. First, because of gaps in the satellite data we have been forced to use the climatological average data for the month of the cruise. This is bound to degrade the correlation, particularly for a species with as dynamic a marine cycle as $\mathrm{CH}_{3} \mathrm{Br}$. Second, the satellite data have been found to significantly underestimate chlorophyll when compared to shipboard observations in the eastern Pacific [Chavez, 1995] and elsewhere [Balch et al., 1992]. It is likely that this accounts for the offset between the regression lines. When the satellite data are adjusted by the empirical relation $C h l_{\text {ship }}=1.104 \mathrm{x}$ $10\left(\left(\log \left(C h l_{\text {sat }}\right)+0.4393\right) / 0.8058\right)$ [Chaveż, 1995], the Cruise $A$ chlorophyll data are more typical of the sampled waters, and both data sets fall along a single regression line similar to that obtained from the Cruise $B$ data alone, with $r=0.86$ (Figure 4b).

This linear relationship was incorporated into the $\mathrm{CH}_{3} \mathrm{Br}$ model. In the case of Cruise $A$ (Figure 5a), the northern hemisphere results are not changed substantially by the inclusion of the productivity effect, since chlorophyll abundances at these latitudes did not deviate far from the 

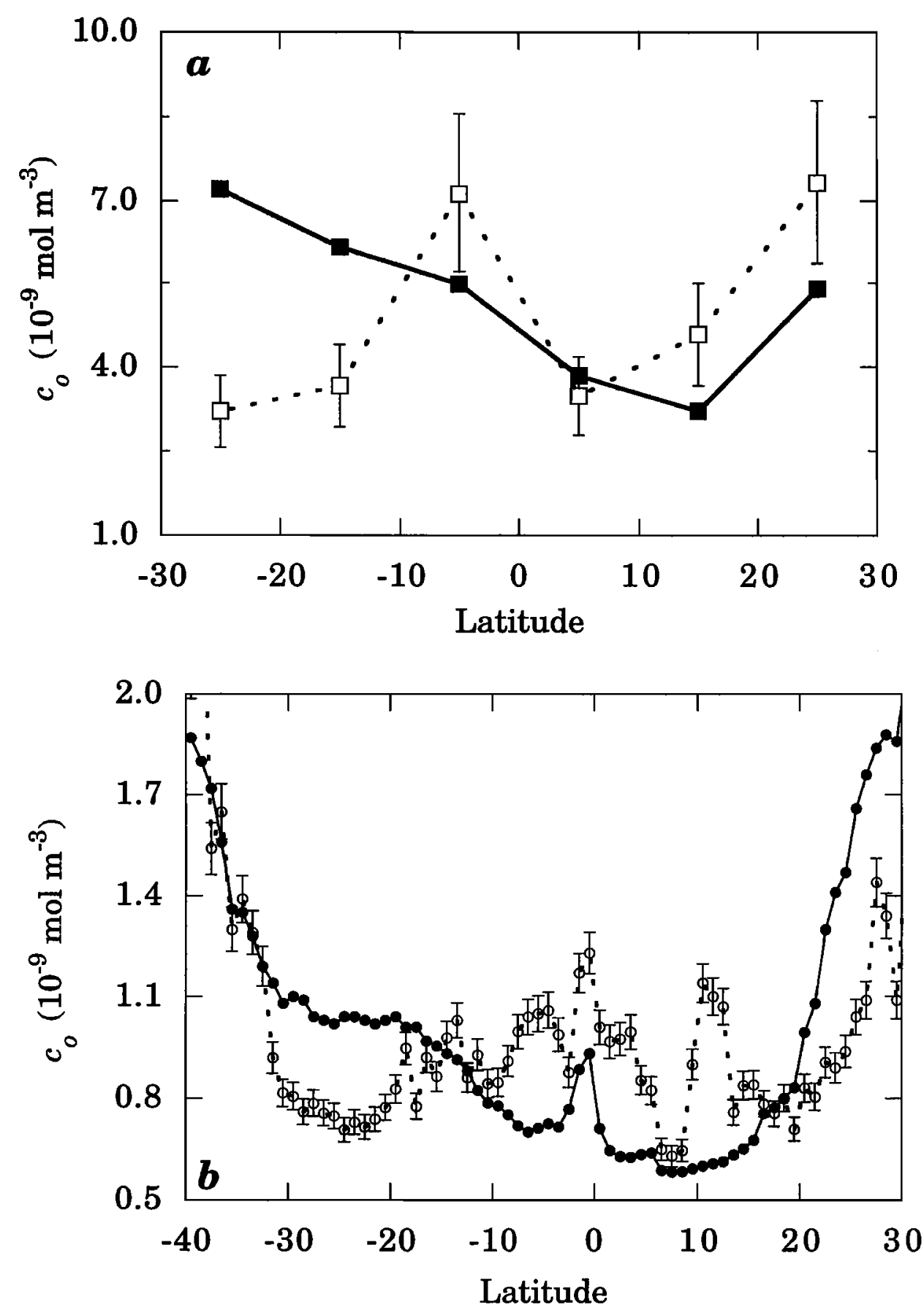

Figure 3. Comparisons of model predictions (solid symbols) with observed $\mathrm{CH}_{3} \mathrm{Br}$ concentrations (open symbols). (a) Cruise $A$; (b) Cruise $B$. Data have been averaged as described in the text. Observational uncertainties are $\pm 2 \sigma$, as reported in Singh et al. [1983] and Lobert et al. [1995]. This model includes only the effect of temperature on the kinetics of $\mathrm{CH}_{3} \mathrm{Br}$ loss in seawater.

regional mean. However, the results for the southern latitudes are improved considerably. In this case, the model results are within $\approx 50 \%$ of the observations for every bin.

Although the constant production model fits the Cruise $B$ data fairly well, inclusion of the productivity effects leads to a significantly better fit (Figure 5b). In particular, the depression between $30^{\circ} \mathrm{S}$ and $20^{\circ} \mathrm{S}$ is reproduced, as are many of the small-scale variations from $20^{\circ} \mathrm{S}$ to $20^{\circ} \mathrm{N}$. The model still overestimates the observations north of $20^{\circ} \mathrm{N}$, but to a lesser degree. Overall, the model results and observational data now agree to within $15 \%$ for nearly all latitudes.

These results clearly indicate a connection between $\mathrm{CH}_{3} \mathrm{Br}$ 

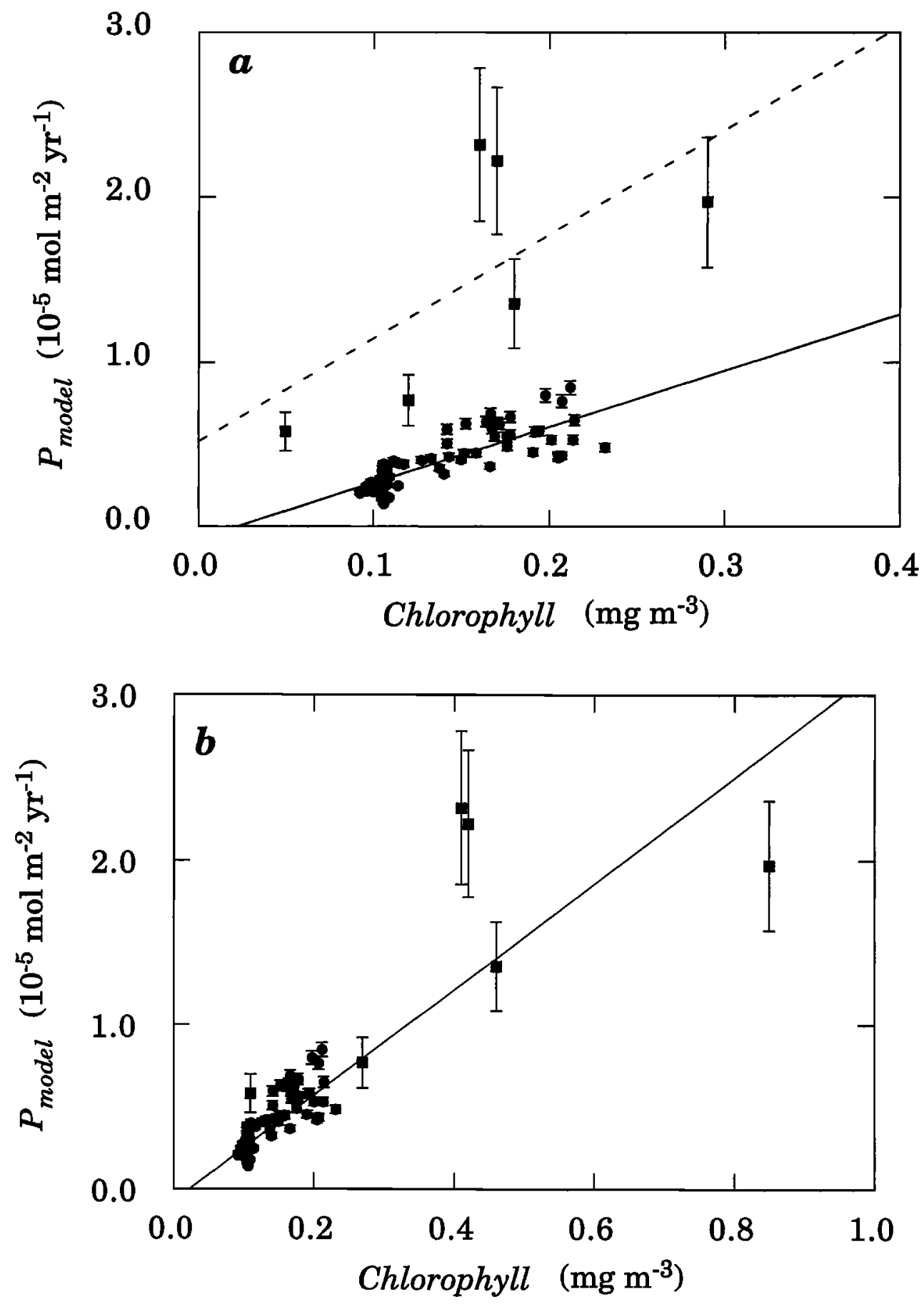

Figure 4. (a) Comparison of the $\mathrm{CH}_{3} \mathrm{Br}$ production rate needed to provide the observed levels of $\mathrm{CH}_{3} \mathrm{Br}\left(P_{\text {model }}\right)$ with observed chlorophyll concentrations. $P_{\text {model }}$ is calculated from measurements of $T$ and $c_{o}$ made during Cruise $A$ (squares) and Cruise $B$ (circles). Chlorophyll data are from satellite observations (Cruise $A$ ) and ship-based measurements (Cruise $B$ ). $P_{\text {model }}$ uncertainties are based on the reported uncertainties for the $\mathrm{CH}_{3} \mathrm{Br}$ measurements used to calculate $P_{\text {model }}$. The best fit line for each data set is indicated. The correlation coefficients are $r=0.66$ (Cruise $A$ ) and $r=0.82$ (Cruise $B$ ). (b) Identical to (a), but with satellite data corrected to match ship-based chlorophyll measurements, as described in the text. The combined data are fit by the line $y=m x+b, m=3.2 \times 10^{-5}, b=-2.8 \times 10^{-7}$. $r=0.86$. 

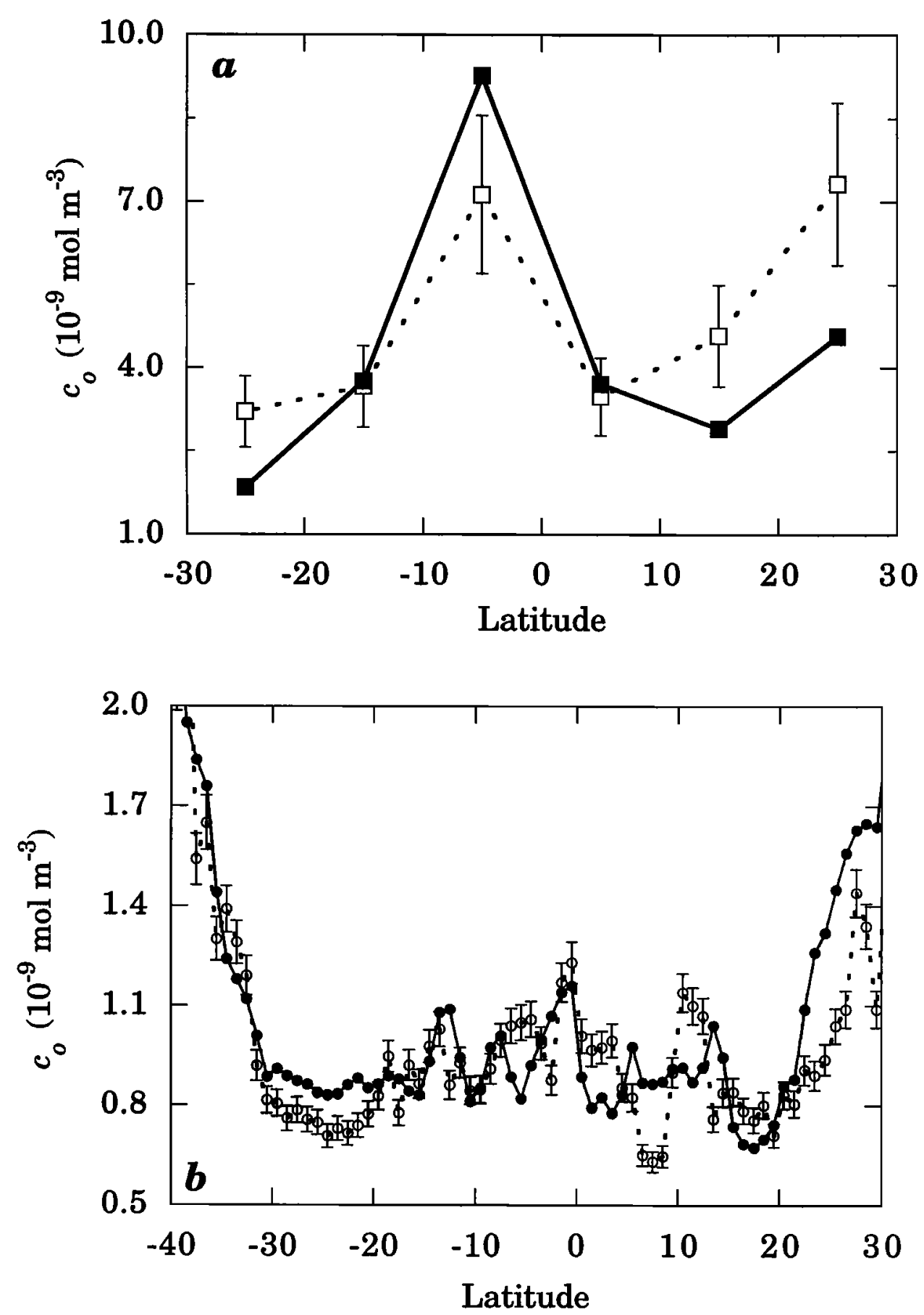

Figure 5. Identical to Figure 3, including the effect of temperature on $\mathrm{CH}_{3} \mathrm{Br}$ loss rates, and latitudinal variation in $\mathrm{CH}_{3} \mathrm{Br}$ production rates. Production rates are adjusted to follow chlorophyll observations, as described in the text. 
and overall biological productivity in seawater, despite the crudeness of the calculations (especially the assumptions of uniform mixed-layer temperature and depth and the omission of any corrections for variable surface windspeed). This accounts for a large fraction of the observed latitudinal variation in seawater $\mathrm{CH}_{3} \mathrm{Br}$. Previously, unsuccessful examinations of $\mathrm{CH}_{3} \mathrm{Br}$ marine data for this relationship [Khalil et al., 1993] may have been complicated by temperature effects; simple comparisons of $c_{o}$ and chlorophyll will not show a high degree of correlation unless all sampled waters are at uniform temperature. Variations in both $k_{d}(T)$ and $P$ must be considered when modeling $c_{o}$.

This correlation, observed across a range of productivities, has serious implications for future observational studies. Since marine primary production is highly variable both geographically and temporally [e.g., Feldman, 1989; Michaels et al., 1994], it is likely that the same is true of marine $\mathrm{CH}_{3} \mathrm{Br}$ production rates. Thus estimates of the global average $\mathrm{CH}_{3} \mathrm{Br}$ flux based on extrapolation of measurements made in limited geographic areas over short periods of time may err substantially, unless appropriate corrections are made for these effects. Although geographic variations in the rate of $\mathrm{CH}_{3} \mathrm{Br}$ production are sometimes considered explicitly [e.g., Singh and Kanakidou, 1993] or implicitly [e.g., Lobert et al., 1995], seasonal or other short-term productivity variations typically are not. Since the residence time of $\mathrm{CH}_{3} \mathrm{Br}$ in the oceans is short, this effect should not be overlooked.

While our findings suggest that $\mathrm{CH}_{3} \mathrm{Br}$ is a general product of the marine biota, identification of the ultimate $\mathrm{CH}_{3} \mathrm{Br}$ seawater source remains an outstanding area of research. Studies of phytoplankton in the laboratory cannot easily account for the necessary rate of $\mathrm{CH}_{3} \mathrm{Br}$ production, and at least one small-scale field study revealed no connection between methyl halide concentrations and phytoplankton abundance [Tokarczyk and Moore, 1994; Moore et al., 1995]. It is possible that $\mathrm{CH}_{3} \mathrm{Br}$ production rates are extremely species specific, much like that of another important trace species, dimethylsulfide (DMS) [Keller, 1991]. Further complications would arise if $\mathrm{CH}_{3} \mathrm{Br}$ production in the oceans were not a direct function of cell division or photosynthesis, as observed in some laboratory cultures [Scarratt and Moore, 1995]. Combined, these effects would make direct correlation of $\mathrm{CH}_{3} \mathrm{Br}$ production and primary production particularly difficult in the laboratory and in limited field studies. This situation is not without precedent. For example, over small scales, correlation of DMS concentration and chlorophyll have been difficult to make. However, over larger scales, similar to those used here, such correlations have been observed [Falkowski et al., 1992].

\section{Extrapolations to the Global Ocean: Cruises A and B Compared}

Cruise $A$ and Cruise $B$ observations have been used to justify a large net $\mathrm{CH}_{3} \mathrm{Br}$ ocean source and a small net ocean sink, respectively [Singh et al., 1983; Singh and Kanakidou, 1993; Lobert et al., 1995]. The difference arises largely from the different seawater $\mathrm{CH}_{3} \mathrm{Br}$ concentrations observed in the two studies. These have led to different estimates of $\mathrm{CH}_{3} \mathrm{Br}$ production rates and/or saturation anomalies, which have then been extrapolated to the entire ocean. However, as demonstrated above, the variations of $\mathrm{CH}_{3} \mathrm{Br}$ concentrations measured during each cruise can be predicted simply on the basis of observed temperature and chlorophyll along each shiptrack. The same simple model can be used to reconcile the two studies.

When extrapolating the Cruise $B$ observations, Lobert et al. [1995] included temperature and productivity variations implicitly, since they determined mean saturation anomalies (saturation anomaly $\left.=\left(H(T) c_{o}-p_{a} \times 10^{-12}\right) /\left(p_{a} \times 10^{-12}\right)\right)$ for characteristic ocean regions sampled during the cruise (i.e., "open ocean", "coastal", and "upwelling"). These were summed in proportion to the area of the ocean represented by each region. To the extent that temperature and $\mathrm{CH}_{3} \mathrm{Br}$ production rates in each characteristic region are truly representative, this approach is valid. Their open ocean results are summarized in Table 1 , along with the mean sea surface temperature observed for this region $\left(21.9^{\circ} \mathrm{C}\right)$. Since it accounts for $80 \%$ of ocean area, the open ocean region dominates the $\mathrm{CH}_{3} \mathrm{Br}$ budget. Although a mean value of $17^{\circ} \mathrm{C}$ has been widely used as an average upper ocean temperature [Sverdrup et al., 1942], open ocean SSTs are substantially higher than this. The value of $21.9^{\circ} \mathrm{C}$ is more representative.

Singh et al. [1983] inferred a large global ocean source of $\mathrm{CH}_{3} \mathrm{Br}$ but did not account for either temperature or production variations in extrapolating Cruise $A$ results. Sing $h$ and Kanakidou [1993] made the significant observation that Cruise $A$ sampled waters close to the continental margins, where marine productivity is much higher than is typical of the open ocean. However, they accounted for this variation in a simplistic manner, as discussed earlier, and did not account for temperature effects. Using (2), and the exchange model of Liss and Slater [1972], we have extrapolated the Cruise $A$ data to the open oceans. We have assumed that the rate of $\mathrm{CH}_{3} \mathrm{Br}$ production in the open ocean is one fourth of the average rate in the waters sampled by Cruise $A$. This is consistent with the ratio of the mean chlorophyll abundance along the Cruise $A$ shiptrack to the mean abundance in the open ocean (derived from the CZCS data set). For consistency, the mean open ocean temperature used by Lobert et al. [1995] is also incorporated here, as are their average open ocean values for $H\left(6.7 \times 10^{-3} \mathrm{~m}^{3}\right.$ atm mol-1) and $K_{l}(1.8$ $\times 10^{3} \mathrm{~m} \mathrm{yr}^{-1}$ ). Note that this value of $H$ is the average of the values calculated at individual data points along the portions of the shiptrack in open ocean waters. Since $H$ is not a linear function of $T$, the open ocean value cannot be simply calculated from the mean open ocean temperature. This extrapolation of the Cruise $A$ observations (Table 1) predicts a net sink of $\approx 0.14 \mathrm{Gmol} \mathrm{yr}^{-1}, D_{o}=1.22 \mathrm{Gmol} \mathrm{yr}^{-1}$, and $P_{o}=1.08 \mathrm{Gmol} \mathrm{yr}^{1}$. We consider this surprisingly good agreement with the results of Lobert et al. [1995], considering the simplicity of the model. Apparently, the Cruise $A$ data set does not contradict the Cruise $B$ observations.

However, it should be recognized that these extrapolations are extremely sensitive to the assumed temperature of the upper ocean. A $12 \%$ increase in the average open ocean SST doubles the magnitude of the net sink to $\approx 0.28 \mathrm{Gmol} \mathrm{yr}^{-1}$. Conversely, a $12 \%$ decrease in the mean open ocean SST decreases the rate of $\mathrm{CH}_{3} \mathrm{Br}$ loss in seawater such that $F_{\text {net }}$ reverses direction. Combined with the small net evasion of 
Table 1. Estimates of Open Ocean $F_{\text {net }}, D_{o}$ and $P_{o}$ Based on Cruise $A$ and Cruise $B$ Observations

\begin{tabular}{ccccc}
\hline & $\begin{array}{c}\mathrm{T}, \\
{ }^{\circ} \mathrm{C}\end{array}$ & $\begin{array}{c}F_{\text {net }} \\
\mathrm{Gmol} \mathrm{yr}^{-1}\end{array}$ & $\begin{array}{c}D_{o} \\
\mathrm{Gmol} \mathrm{yr}^{-1}\end{array}$ & $\begin{array}{c}P_{o}, \\
\mathrm{Gmol} \mathrm{yr}^{-1}\end{array}$ \\
\hline \multirow{2}{*}{ Cruise $A^{\mathrm{a}}$} & 19.3 & 0.01 & 1.07 & 1.08 \\
& 21.9 & -0.14 & 1.22 & 1.08 \\
& 24.5 & -0.28 & 1.36 & 1.08 \\
Cruise $B^{\mathrm{b}}$ & 21.9 & -0.17 & 1.28 & 1.11 \\
\hline
\end{tabular}

aResults of this study, based on the data of Singh et al. [1983] and Singh and Kanakidou [1993]. $F_{n e t}$ and $D_{o}$ were derived from $c_{o}$ which was calculated from equation (2), using the tabulated values of $T$ and $P_{v}$. Mean open ocean $P_{o}$ was derived by scaling to observed chlorophyll abundances, as described in the text.

bResults of Lobert et al. [1995]. $F_{n e t}$ was derived from the observed mean saturation anomaly, and $D_{o}$ was calculated using mean $c_{o}$ and $T . P_{o}$ is the sum of $F_{n e t}$ and $D_{o}$.

$\mathrm{CH}_{3} \mathrm{Br}$ observed in coastal and upwelling waters [Lobert et al., 1995], this would result in a small net $\mathrm{CH}_{3} \mathrm{Br}$ ocean source. Thus although a large open ocean source for $\mathrm{CH}_{3} \mathrm{Br}$ now seems unlikely, a small source is still possible, if average open ocean temperatures are slightly different from those observed by Lobert et al. [1995].

Regardless, the elimination of a large open ocean source is problematic for the $\mathrm{CH}_{3} \mathrm{Br}$ atmospheric budget, since known sinks of $\geq 100 \mathrm{Gmol} \mathrm{yr}^{-1}$ are not balanced by the remaining known sources. One source which may have been overlooked is evasion from polar oceans. In particular, the Southern Ocean, which comprises approximately $10 \%$ of ocean area, is a region of high primary production and very low sea surface temperature. These factors may combine to produce a high rate of $\mathrm{CH}_{3} \mathrm{Br}$ production, a low rate of in situ consumption and, hence, a large net flux to the atmosphere. Using available chlorophyll and temperature data for the Southern Ocean [Comiso et al., 1993], a simple extrapolation based on the relationship in Figure $4 \mathrm{~b}$ and our model (equations (1)-(3)) predicts an extremely high contribution from these waters to the total $\mathrm{CH}_{3} \mathrm{Br}$ source (Table 2). This contribution may have an extremely large seasonal variability.

The contribution from extreme northern latitudes is likely to be a smaller fraction of the total source since there is less exposed ocean at these latitudes. However, $\mathrm{CH}_{3} \mathrm{Br}$ from these waters could have an important regional effect, since organobromines have been strongly implicated in Arctic ozone loss [e.g., Leaitch et al., 1994; Li et al., 1994].

Such extrapolations should be regarded cautiously, as they are subject to all the uncertainties inherent in the CZCS data set discussed above. Additionally, we have assumed that the relationship between chlorophyll and $\mathrm{CH}_{3} \mathrm{Br}$ production rates observed in low-latitude waters can be directly applied to extreme latitudes. Since the agent responsible for $\mathrm{CH}_{3} \mathrm{Br}$ production has not been identified, this assumption may be flawed. Clearly, there is an urgent need for characterization of $\mathrm{CH}_{3} \mathrm{Br}$ in high-latitude seawater.

The sensitivity of marine $\mathrm{CH}_{3} \mathrm{Br}$ to temperature suggests that climate change can affect the direction and magnitude of the net $\mathrm{CH}_{3} \mathrm{Br}$ ocean-atmosphere flux. Since the amount of $\mathrm{CH}_{3} \mathrm{Br}$ produced in seawater each year $(\approx 1.1 \mathrm{Gmol})$ is comparable to the amount of $\mathrm{CH}_{3} \mathrm{Br}$ emitted from all sources to the atmosphere $(0.80-1.2 \mathrm{Gmol})$, even small perturbations to this flux may significantly alter the atmospheric partial pressure of $\mathrm{CH}_{3} \mathrm{Br}$. A coupled ocean-atmosphere model is needed to explore this problem. Such a model is discussed below.

\section{Atmospheric $\mathrm{CH}_{3} \mathrm{Br}$ : A Coupled Ocean- Atmosphere Model}

\section{Model Description}

Variations in $c_{o}$ such as those modeled above translate directly into variations in the ocean-atmosphere flux, which are reflected in the average atmospheric abundance of $\mathrm{CH}_{3} \mathrm{Br}$ if the system is permitted to equilibrate over timescales greater than the atmospheric residence time, $\tau_{\mathrm{CH}_{3} \mathrm{Br}}$. This effect can be studied using a simple, two-box model which couples the upper ocean and troposphere (Figure 6), following the treatment of Butler [1994]. This approach assumes that the upper ocean and troposphere are well mixed. Thus geographic heterogeneities, such as those discussed in the previous section, are not considered. Instead, this model lets us examine the global average abundance of $\mathrm{CH}_{3} \mathrm{Br}$ in the atmosphere and ocean for different values of upper ocean temperature and/or different rates of $\mathrm{CH}_{3} \mathrm{Br}$ production.

The upper ocean budget is again described by (1). The atmospheric budget balances destruction by reaction with $\mathrm{OH}$ (and possible land sinks) against inputs from the oceans, anthropogenic sources $\left(R_{\text {anthro }}\right)$, and other sources, such as biomass burning $\left(R_{\text {other }}\right)$ :

Table 2. Estimates of $F_{n e t}, D_{o}$ and $P_{o}$ in the Southern Ocean

\begin{tabular}{lcccccc}
\hline & $\begin{array}{c}\mathrm{T}, \\
{ }^{\circ} \mathrm{C}\end{array}$ & $\begin{array}{c}\mathrm{CZCS} \mathrm{Chl,} \\
\mathrm{mg} \mathrm{m}^{-3}\end{array}$ & $\begin{array}{c}\mathrm{CH}_{3} \mathrm{Br}, \\
\mathrm{mol} \mathrm{m}^{-3}\end{array}$ & $\begin{array}{c}F_{\text {net }}, \\
\mathrm{Gmol} \mathrm{yr}^{-1}\end{array}$ & $\begin{array}{c}D_{o}, \\
\mathrm{Gmol} \mathrm{yr}^{-1}\end{array}$ & $\begin{array}{c}P_{o}, \\
\mathrm{Gmol} \mathrm{yr}^{-1}\end{array}$ \\
\hline January & 12 & 0.25 & $4.09 \times 10^{-9}$ & 0.14 & 0.14 & 0.27 \\
July & 8 & 0.45 & $1.38 \times 10^{-8}$ & 0.74 & 0.27 & 1.01 \\
Annual Average & 10 & 0.35 & $8.93 \times 10^{-9}$ & 0.43 & 0.21 & 0.64 \\
\hline
\end{tabular}

Based on seasonal chlorophyll and temperature data from Comiso et al. [1993].

CZCS is coastal zone color scanner. 


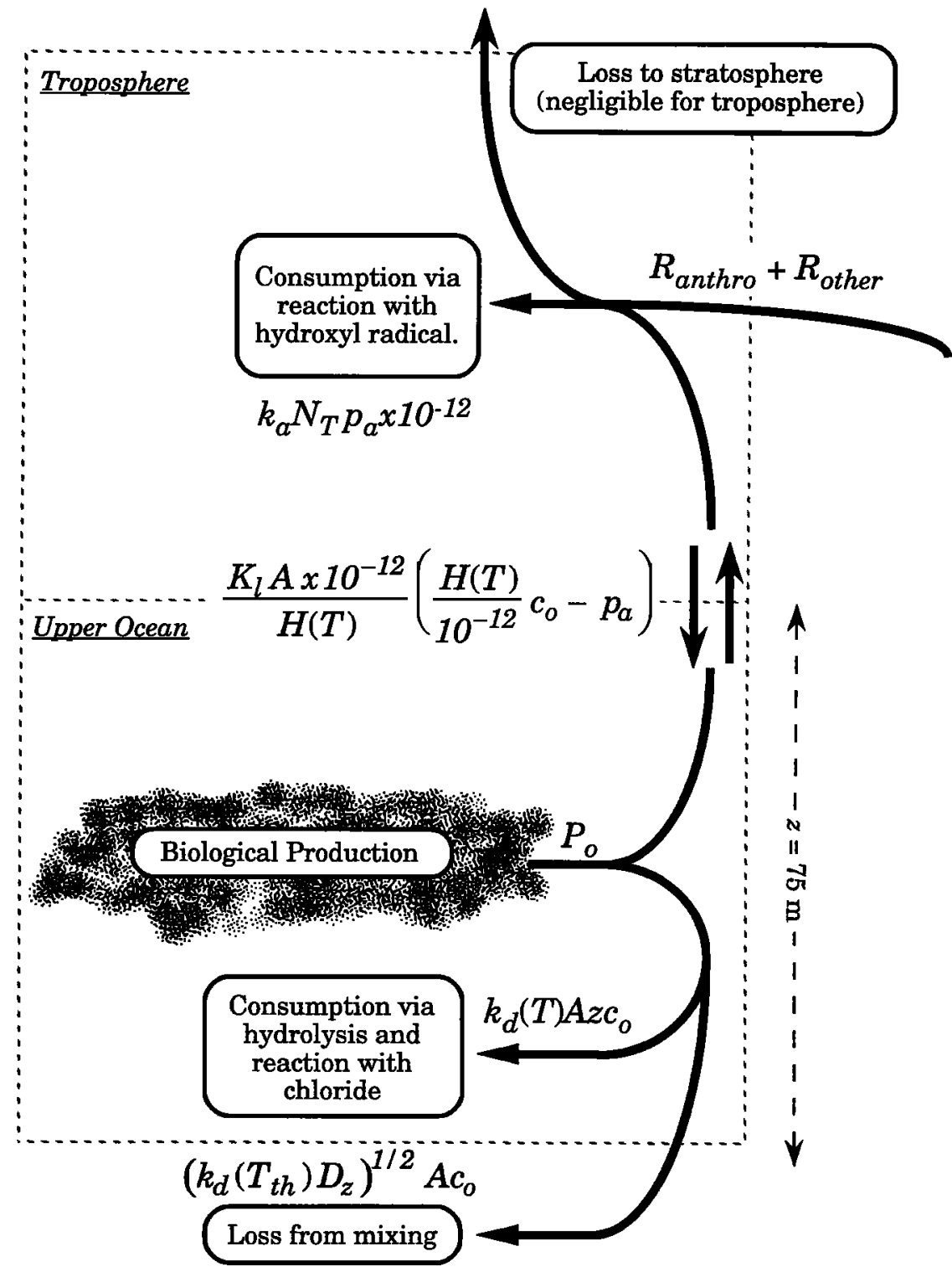

Figure 6. Schematic presentation of the coupled ocean atmosphere model. Variables are defined in the text. Inputs and outputs are expressed in units of mole per year.

$$
\begin{aligned}
\frac{d p_{a}}{d t}= & \frac{R_{\text {anthro }}+R_{\text {other }}}{N_{T} \times 10^{-12}} \\
& +\frac{K_{l} A \times 10^{-12}}{N_{T} H(T)}\left(\frac{H(T)}{10^{-12}} c_{o}-p_{a}\right)-k_{a} p_{a}
\end{aligned}
$$

where $k_{a}$ is the rate of loss from the atmosphere $\left(\approx 0.56 \mathrm{yr}^{-1}\right.$ [Mellouki et al., 1992]), $N_{T}$ is the total number of moles in the atmosphere $\left(1.8 \times 10^{20} \mathrm{~mol}\right)$, and $A$ is the global ocean surface area $\left(3.61 \times 10^{14} \mathrm{~m}^{2}\right)$. Although the rate of $\mathrm{CH}_{3} \mathrm{Br}$ evasion to the stratosphere dominates the stratospheric bromine budget, this is a negligible sink for the troposphere and is therefore not included in $k_{a}$.

The coupled model is solved by assuming that steady state conditions exist in each box. Equations (1) and (4) can be simplified by using (3), and by replacing the net exchange coefficient, $K_{l}$, with separate coefficients $\left(k_{a}(T)=K_{l} A / H(T) N_{T}\right.$; $\left.k_{b}=K_{l} / z\right)$. We can then solve for $c_{o}$ or $p_{a}$ :

$$
\begin{aligned}
& c_{o}=\frac{P_{o}+\left(R_{\text {anthro }}+R_{\text {other }}\right)(1-\alpha)}{A z\left(k_{o}(T)+k_{\beta} \alpha\right)} ; \alpha=\frac{k_{a}}{k_{a}+k_{\alpha}(T)} \\
& p_{a}=\frac{R_{\text {anthro }}+R_{\text {other }}+P_{o}(1-\beta)}{N_{T}\left(k_{a}+k_{\alpha} \beta\right)} \times 10^{12} ; \beta=\frac{k_{o}(T)}{k_{o}(T)+k_{\beta}}
\end{aligned}
$$

where $P_{o}=P A$, for convenient comparison of the total marine production term with $R_{\text {anthro }}$ and $R_{\text {other }}$. These equations can be used to explore the effects of global-scale variations in $P_{o}$ and $T$ on $c_{o}$ and $p_{a}$. A complete model built on these equations requires a multibox approach to account for the 

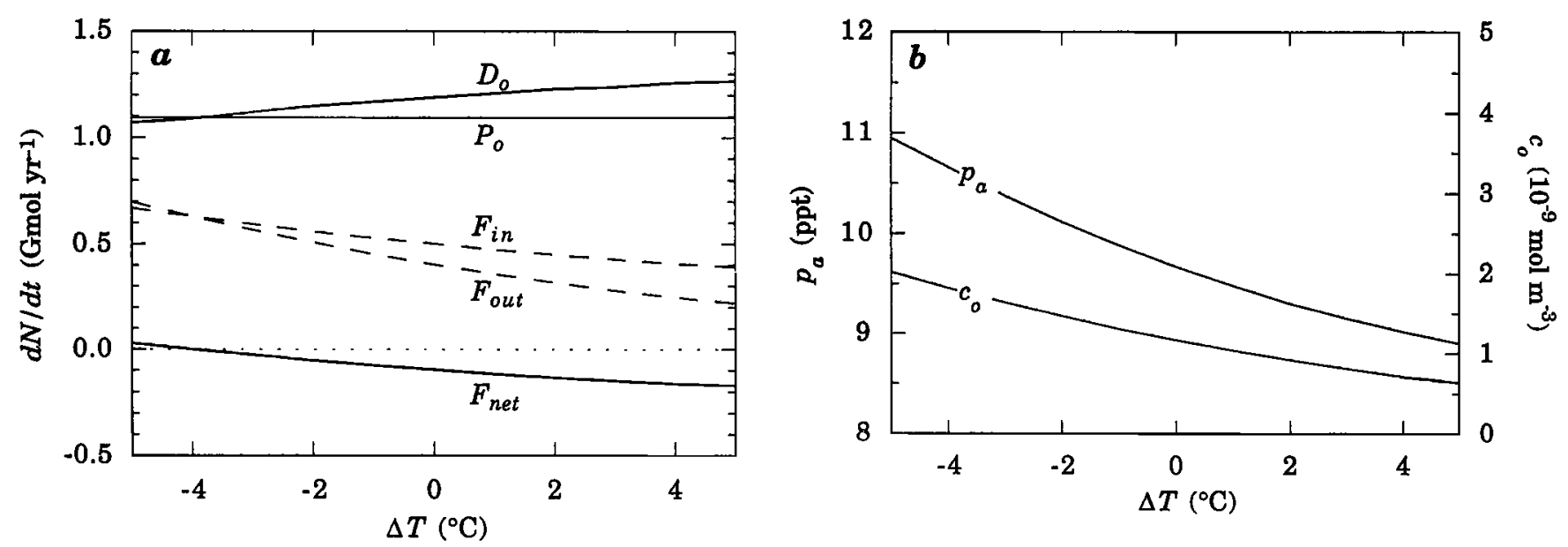

Figure 7. The effect of temperature of the $\mathrm{CH}_{3} \mathrm{Br}$ cycle in the present atmosphere and open ocean $\left(R_{\text {anthro }}=0.40 \mathrm{Gmol}\right.$ $\left.\mathrm{yr}^{-1}, R_{\text {other }}=0.65 \mathrm{Gmol} \mathrm{yr}^{-1}, \mathrm{P}_{o}=1.08 \mathrm{Gmol} \mathrm{yr}^{-1}, \mathrm{z}=75 \mathrm{~m}\right) . \Delta T=T-21.9^{\circ} \mathrm{C}$. (a) The rate of $\mathrm{CH}_{3} \mathrm{Br}$ consumption in seawater $\left(D_{o}\right)$, the gross fluxes in and out of the ocean $\left(F_{\text {in }}\right.$ and $\left.F_{o u l}\right)$, and the net oceanic flux $\left(F_{n e t}\right)$; (b) the resulting variation of $\mathrm{CH}_{3} \mathrm{Br}$ concentrations in seawater $\left(c_{o}\right)$ and in the atmosphere $\left(p_{a}\right)$.

wide variations of temperature and productivity in different waters. However, the intent of this study is to point the way for future work in as simple and illustrative a manner as possible. Thus in the calculations below we have modeled only the interaction of the atmosphere with the open ocean (therefore $A=0.8 \times 3.61 \times 10^{14} \mathrm{~m}^{2}$ ). Since these waters appear to dominate the $\mathrm{CH}_{3} \mathrm{Br}$ system [Lobert et al., 1995], this is a reasonable first-order approach.

The utility of these equations is somewhat hampered by uncertainties in the estimates of $R_{\text {anthro }}$ and $R_{\text {other }}$ [e.g., Albritton and Watson, 1992; Manö and Andreae, 1994]. Since $R_{\text {anthro }}$ and $R_{\text {other }}$ are assumed to be independent of temperature and are by definition independent of $P_{o}$, these sources "dilute" the atmospheric impact of variations in $F_{n e t}$; the resulting variation of $p_{a}$ will correlate inversely with the magnitude of these sources relative to $F_{\text {net }}$. Thus rigorous modeling of the global response of $p_{a}$ to perturbations in the anthropogenic source is not possible until the relative magnitudes of these sources are determined. Below, we illustrate the effects of temperature and productivity changes in a semiquantitative fashion, using reasonable literature values for $R_{\text {anthro }}$ and $R_{\text {other. }}$. Our intent is to point out some general implications of temperature and productivity effects which should be contemplated as better source estimates become available in coming years. For the purpose of this

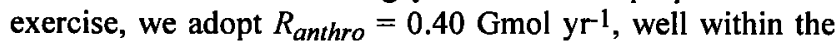
latest range of published estimates [e.g., Butler, 1995]. By subtraction from a total source of $1.05 \mathrm{Gmol} \mathrm{yr}^{-1}$ [Lobert et al., 1995], $R_{\text {other }}=0.65 \mathrm{Gmol} \mathrm{yr}: 1$.

Although there are undoubtedly feedbacks between variations in temperature and variations in $\mathrm{CH}_{3} \mathrm{Br}$ production, for simplicity we will begin by considering the effects of these variables separately. The complications are addressed further below.

\section{Temperature Effects}

Figure 7 illustrates the effects of temperature over a $10^{\circ} \mathrm{C}$ range, centered at an average open ocean mixed-layer temperature of $21.9^{\circ} \mathrm{C}$ [Lobert et al., 1995]. This model also incorporates a mixed layer of $75 \mathrm{~m}$ depth, and $T_{t h}=15^{\circ} \mathrm{C} . P_{o}$ is assumed invariant with temperature, and is equal to the value in Table 1. As temperature increases, the rate constant for $\mathrm{CH}_{3} \mathrm{Br}$ loss rises, so that $D_{o}$ rises from $\approx 1.1$ to $1.3 \mathrm{Gmol}$ $\mathrm{yr}^{-1}$ (Figure 7a), and $c_{o}$ falls from $2.0 \times 10^{-9}$ to $6.3 \times 10^{-10}$ mol m-3 (Figure 7b). The drop in $c_{o}$ is reflected in $F_{\text {out }}$, the gross flux of $\mathrm{CH}_{3} \mathrm{Br}$ out of the ocean (Figure 7a). $F_{\text {in }}$, the gross rate of $\mathrm{CH}_{3} \mathrm{Br}$ invasion, also falls with increasing temperature, due to decreasing solubility. However, this effect is not large enough to compensate for the drop in $F_{\text {out }}$, causing $F_{\text {net }}$ to decrease and change direction, from 0.03 to -

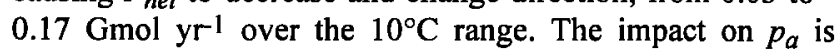
substantial; a decrease of $\approx 20 \%$ is predicted, from 11 to 8.9 ppt.

These findings have important implications for the response of atmospheric $\mathrm{CH}_{3} \mathrm{Br}$ to changes in the size of the anthropogenic source. Since $p_{a}$ is sensitive to temperature, climatological temperature variations may have more effect on atmospheric $\mathrm{CH}_{3} \mathrm{Br}$ than small changes in the source strength. As shown in Figure 8 (region a), in the case of a $5^{\circ} \mathrm{C}$ temperature rise, $p_{a}$ does not climb above the present level, even if anthropogenic emissions increase by $25 \%$ relative to the assumed present value of $0.40 \mathrm{Gmol} \mathrm{yr}^{-1}$. Since surface ocean warming of $1^{\circ}$ to $5^{\circ} \mathrm{C}$ has been predicted to result from $\mathrm{CO}_{2}$-induced global warming in coming decades [e.g., Bretherton et al., 1990], it is plausible to suggest that such warming will reduce the level of $\mathrm{CH}_{3} \mathrm{Br}$ in the atmosphere even if anthropogenic emissions are not changed, or increase slightly. Ironically, the consequences of anthropogenic emissions of $\mathrm{CH}_{3} \mathrm{Br}$ may be lessened by anthropogenic $\mathrm{CO}_{2}$. Conversely, atmospheric $\mathrm{CH}_{3} \mathrm{Br}$ can actually increase, in spite of substantial reductions in the anthropogenic source, if mean temperatures decrease (region b).

Additionally, Figure 8 illustrates that even the complete elimination of anthropogenic $\mathrm{CH}_{3} \mathrm{Br}$ does not reduce atmospheric levels to zero; $7 \mathrm{ppt}$ is the lower limit in our model, neglecting temperature effects. This is in part due to the existence of large nonanthropogenic sources in our model; this remains an active area of research. However, the 


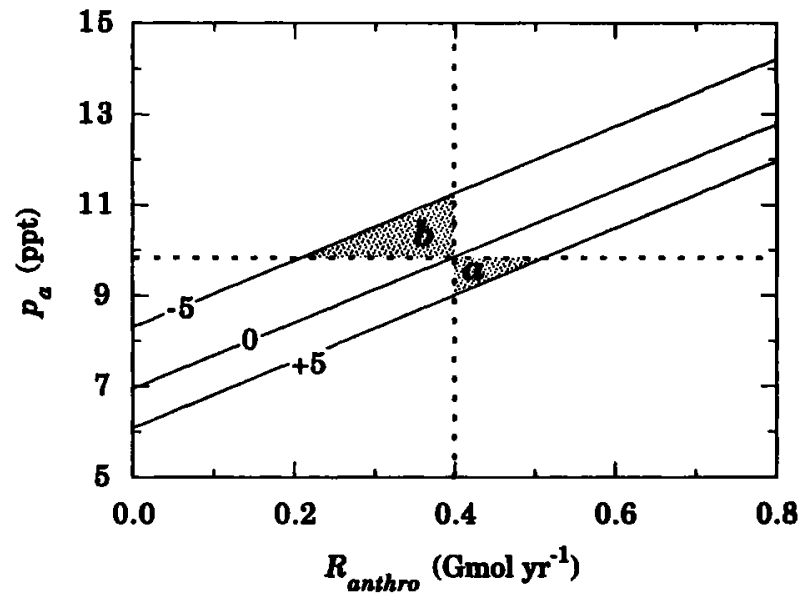

Figure 8. The effect of the anthropogenic source strength $\left(R_{\text {anthro }}\right)$ on atmosphere $\mathrm{CH}_{3} \mathrm{Br}\left(p_{a}\right)$, using the same model as in Figure 7. Results for $\Delta T=-5^{\circ}, 0^{\circ}$, and $+5^{\circ} \mathrm{C}$ are presented. Dotted lines

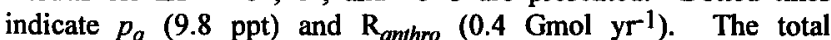

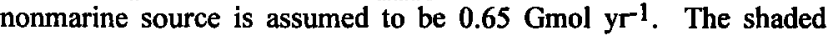
regions are fields in which temperature effects rather than the source strength govern $p_{a}$. In region a, increasing temperature results in lower $p_{a}$, despite small increases in $R_{a n t h r o}$; in region $\mathrm{b}$, decreasing temperature results in higher $p_{a}$, despite small reductions in $R_{a m t h r o}$. Note that for $\Delta T=0$ and $R_{\text {anthro }}=0$, the preindustrial condition, $p_{a}=$ 7.0 ppt. At $R_{\text {anthro }}=0.8 \mathrm{Gmol} \mathrm{yr}^{-1}$, a doubling of the current source, $p_{a}=14.2 \mathrm{ppt}$.

"buffering" of $p_{a}$ by changes in $F_{\text {net }}$ also plays a role, as first suggested by Butler [1994]. Even if all nonmarine sources were eliminated, $\approx 2 \mathrm{ppt}$ of atmospheric $\mathrm{CH}_{3} \mathrm{Br}$ would be supported by evasion from the oceans.

These results also suggest that there may be substantial, natural variations in the atmospheric burden of $\mathrm{CH}_{3} \mathrm{Br}$. For example, the $2^{\circ}-5^{\circ} \mathrm{C}$ global cooling experienced during glacial periods [Folland et al., 1990] would have exerted an upward pressure on $\mathrm{CH}_{3} \mathrm{Br}$ levels. The absence of anthropogenic sources would have led to lower preindustrial values of $p_{a}$ but would also have increased the relative importance of marine chemistry for the atmosphere, since the marine source would have been a larger fraction of total $\mathrm{CH}_{3} \mathrm{Br}$ input. We calculate that under such conditions, upper open ocean temperatures $5^{\circ} \mathrm{C}$ lower than the modern mean would have resulted in a $20 \%$ increase of $p_{a}(7.0$ versus 8.3 ppt), assuming constant $P_{o}$ and nonanthropogenic, nonmarine sources of $0.65 \mathrm{Gmol} \mathrm{yr}^{-1}$.

\section{Productivity Effects}

An analogous set of calculations can be made for constant temperature but variable $P_{o}$ (Figure 9). Here $T$ is held constant at $21.9^{\circ} \mathrm{C}$ while $P_{o}$ is varied $\pm 50 \%$ of the present value. Even over a fraction of this range, the effects are significant. For example, a $20 \%$ rise in $P_{o}$ from the present global average would cause an increase in $F_{n e t}$ of more than a third (Figure 9a). At $P / P_{\text {avg }}=1.5, F_{\text {net }}$ changes sign, and the open ocean becomes a small net $\mathrm{CH}_{3} \mathrm{Br}$ source. Over the full range of $P_{o}$ values considered, $p_{a}$ varies by nearly $25 \%$ (Figure 9b).
Unfortunately, the applicability of these results is uncertain. Although marine productivity varies markedly in most regions on seasonal and longer timescales, the variability of mean open ocean productivity is unclear. Therefore we are reluctant to speculate on the implications of variable $P_{o}$ to the same degree as with variable $T$. We do note, however, that glacial periods are often thought to be times of heightened marine productivity, possibly by as much as a factor of 2 [e.g., Herguera and Berger, 1991; Gingele and Dahmke, 1994]. This would tend to push $\mathrm{CH}_{3} \mathrm{Br}$ levels up during glaciation. If $R_{\text {anthro }}=0$, a $50 \%$ increase in $P_{o}$ would increase $p_{a}$ by $\approx 15 \%$, from 6.8 to $7.8 \mathrm{ppt}$. Thus during glacial periods, productivity and temperature changes could have acted in concert to raise tropospheric $\mathrm{CH}_{3} \mathrm{Br}$ from interglacial, preindustrial values.

While more sophisticated models and a better accounting of $\mathrm{CH}_{3} \mathrm{Br}$ sources and sinks are needed to quantify these effects, it is clear that the geochemistry of $\mathrm{CH}_{3} \mathrm{Br}$ is complex, and that this compound is not directly comparable to other halocarbons, which have only anthropogenic sources and no significant marine chemistry. This complexity must be considered during the formulation of $\mathrm{CH}_{3} \mathrm{Br}$ regulatory guidelines.

\section{Model Validation?}

Ideally, this simple open ocean model would be tested by comparison of model results with measurements of atmospheric $\mathrm{CH}_{3} \mathrm{Br}$ made during periods of multiyear variation in SSTs and/or marine productivity. Although global productivity changes are poorly constrained, sufficiently large global SST variations have occurred in the past. An average increase of $\approx 1^{\circ} \mathrm{C}$ is associated with climatic warming since the late nineteenth century, and glacial surface waters are estimated to have been $2^{\circ}$ to $5^{\circ} \mathrm{C}$ cooler than at present [e.g., Folland et al., 1990]. Unfortunately, $\mathrm{CH}_{3} \mathrm{Br}$ data exist only for the past decade. During this time, the only significant SST changes have been those associated with seasonal cycles and El Nifio events. Seasonal cycles are too short to expect a large global perturbation to $p_{a}$; with $\tau_{\mathrm{CH}_{3} \mathrm{Br}} \approx$ 1.8 years, and a total mass of $\approx 2.1 \mathrm{Gmol}$, average atmospheric $\mathrm{CH}_{3} \mathrm{Br}$ is quite insensitive to 10 to $30 \%$ fluctuations of a small marine sink (or source) on a 0.5 year timescale. A similar argument can be made for the insensitivity of $p_{a}$ to plausible seasonal-scale variations in global or hemispheric $P_{0}$.

El Niño events are unlikely to cause global perturbations for similar reasons. However, since the elevated SSTs and depressed productivities associated with $\mathrm{El}$ Niño conditions typically persist for $\approx 1.5$ years [Cane, 1983; Folland et al., 1990; Philander, 1990], these events might cause an observable regional perturbation of atmospheric $\mathrm{CH}_{3} \mathrm{Br}$ in the tropical Pacific, where El Niño SST effects are localized. Qualitatively, SST warming and productivity retardation during El Ninoo years should work in concert to depress $p_{a}$. Quantitative modeling of the effect on $p_{a}$ is beyond the scope of this paper.

Biomass burning, which is also highly variable geographically and with time, is expected to have similar regional effects on tropospheric $\mathrm{CH}_{3} \mathrm{Br}$. Comprehensive $\mathrm{CH}_{3} \mathrm{Br}$ measurements in the tropical Pacific during future $\mathrm{El}$ 

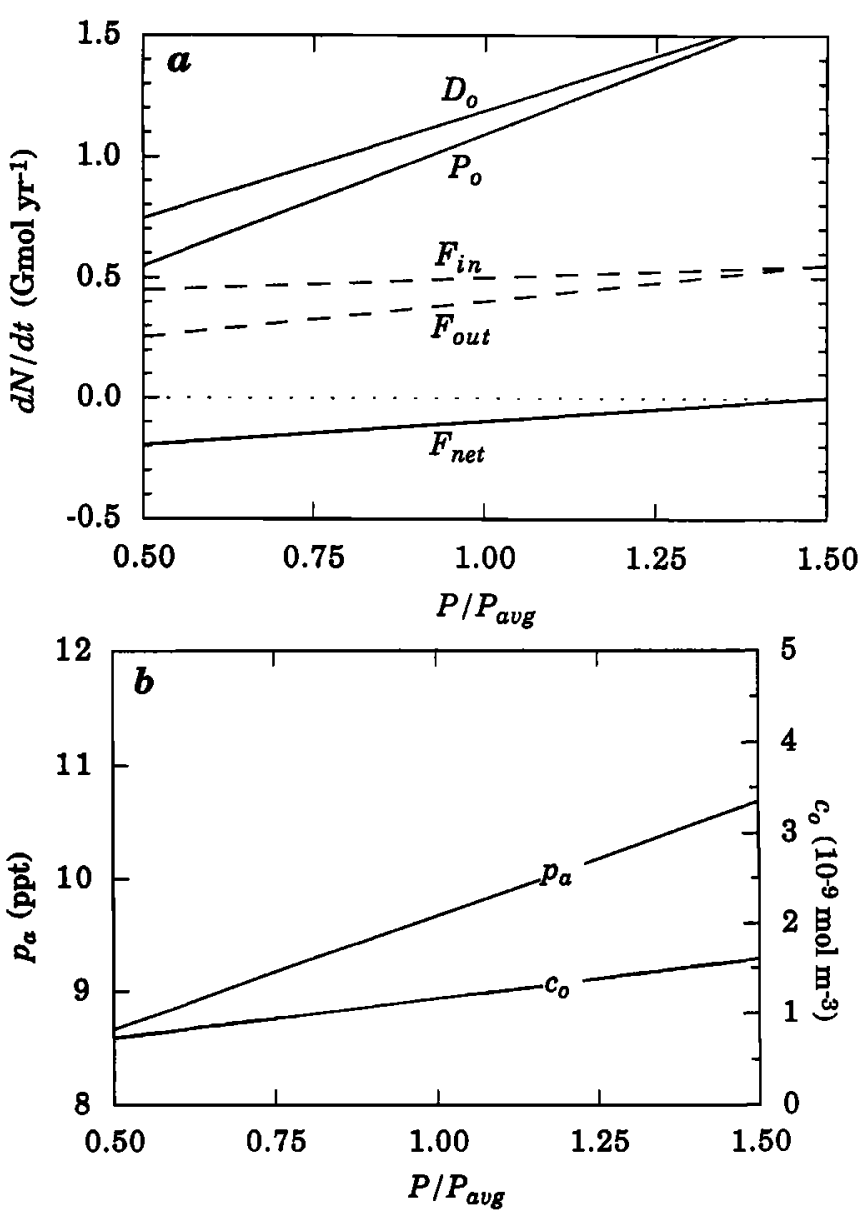

Figure 9. The effect of changes in the rate of $\mathrm{CH}_{3} \mathrm{Br}$ production on the $\mathrm{CH}_{3} \mathrm{Br}$ cycle in the present atmosphere and ocean $\left(R_{\text {anthro }}=0.40\right.$ $\mathrm{Gmol} \mathrm{yr}^{-1}, R_{\text {other }}=0.65 \mathrm{Gmol} \mathrm{yr}^{-1}, P_{o}=1.08 \mathrm{Gmol} \mathrm{yr}^{-1}, z=75 \mathrm{~m}$, $T_{\text {avg }}=21.9^{\circ} \mathrm{C}$ ). Here Figure $9 \mathrm{a}$ and $9 \mathrm{~b}$ are as described in Figure 7 .

Niño events, and at locations close to biomass burning sources, could reveal much about $\mathrm{CH}_{3} \mathrm{Br}$ biogeochemistry.

\section{Other Biological Complications?}

Simulations of global $\mathrm{CH}_{3} \mathrm{Br}$ response to temperature change are dependent on assumptions about the response of biology to such change. Above, we have assumed that the rate of $\mathrm{CH}_{3} \mathrm{Br}$ production is not strongly coupled to temperature. This is unlikely to be the case. However, the direction of any feedback between $\mathrm{CH}_{3} \mathrm{Br}$ production and temperature is unclear.

During El Niño, for example, warmer SSTs are a signature of reduced nutrient flux into the euphotic zone. This reduction is due to a combination of upwelling of water with lower nutrient content as a result of a deeper nutricline and to reduced upwelling intensity. The corollary is a depression in biological productivity of surface waters [Barber and Chavez, 1983; Halpern and Feldman, 1994]. If $\mathrm{CH}_{3} \mathrm{Br}$ production scales with primary productivity, then El Nino's could result in decreased $\mathrm{CH}_{3} \mathrm{Br}$ production and escape to the atmosphere. In this case, the effects of temperature and primary production should work in concert to depress the $\mathrm{CH}_{3} \mathrm{Br}$ flux.
On the other hand, a positive correlation has been observed between temperature and primary production when nutrient supply is not limiting [Eppley, 1972; Malone, 1982; Keller, 1989]. Eppley [1972] quantified this effect $\left(P\left(T_{1}\right) / P\left(T_{2}\right)=\right.$ $10^{0.0275}\left(T_{2}-T_{1}\right)$ ), which would lead to enhanced rates of $\mathrm{CH}_{3} \mathrm{Br}$ production under warmer conditions. However, when incorporated into our model, this effect is strong enough to counteract the influence of temperature on inorganic loss processes. The result is little net change in $p_{a}$ over a $10^{\circ} \mathrm{C}$ range (Figure 10). Thus it is difficult to determine whether, on balance, feedbacks between temperature and biological activity dampen or amplify the effects of temperature on the flux of $\mathrm{CH}_{3} \mathrm{Br}$ from the modern oceans, let alone from the oceans of the past or future.

\section{Summary and Conclusions}

Our examination of the marine geochemistry of $\mathrm{CH}_{3} \mathrm{Br}$ indicates that the rates of loss and production in the water column control the concentration of $\mathrm{CH}_{3} \mathrm{Br}$ in seawater and the direction and magnitude of the $\mathrm{CH}_{3} \mathrm{Br}$ flux between the atmosphere and ocean. Large variations in the rate of chemical loss result from modest temperature variations. Linear scaling of $\mathrm{CH}_{3} \mathrm{Br}$ production rates to chlorophyll content brings models and observations into agreement, which strongly suggests a high rate of biological production of $\mathrm{CH}_{3} \mathrm{Br}$ in seawater. A simple mass balance model which accounts for temperature and biological production can successfully reproduce the latitudinal variations of marine $\mathrm{CH}_{3} \mathrm{Br}$ observed in the eastern Pacific Ocean in two separate studies. When temperature and primary productivity effects are carefully considered, global extrapolations of the open ocean flux from both these data sets can be brought into good agreement. These results demonstrate that the data of Singh et al. [1983], Singh and Kanakidou [1993] and Lobert et al. [1995] are not in conflict, and support Lobert et al. 's [1995] conclusion that the open ocean constitutes a small net sink for $\mathrm{CH}_{3} \mathrm{Br}$, rather than a large net source. This finding presents a new challenge, since anthropogenic emissions and biomass burning are believed to total only $\approx 60-80 \mathrm{Gmol} \mathrm{yr}^{-1}$, out of the $90-120 \mathrm{Gmol} \mathrm{yr}^{-1}$ total source estimated by Lobert et al.

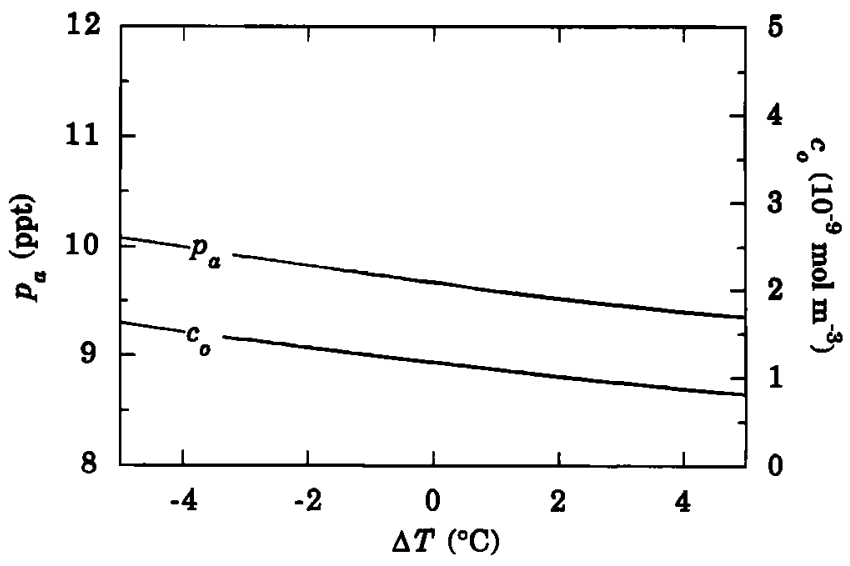

Figure 10. The same as Figure $7 \mathrm{~b}$, but including the effect of temperature-dependence on biological productivity, $P\left(T_{1}\right) / P\left(T_{2}\right)=$ $10^{0.0275}\left(T_{2}-T_{1}\right)$ [Eppley, 1972]. 
[1995]. Either the magnitudes of these sources have been underestimated, or a large $\mathrm{CH}_{3} \mathrm{Br}$ source remains unidentified. This deficit may be filled by large emissions from the Southern Ocean, a result of the combination of low temperature and high productivity in these waters.

Since temperature and marine productivity are sensitive to climate, both the direction and magnitude of the oceanic flux should be sensitive to global climate change. Since the total amount of $\mathrm{CH}_{3} \mathrm{Br}$ produced and destroyed annually in the ocean is comparable to the flux to the atmosphere from nonmarine sources, even small perturbations of the marine cycle can produce significant atmospheric effects. Changes in tropospheric $\mathrm{CH}_{3} \mathrm{Br}$ due to changes in the ocean term are somewhat buffered by the residence time of $\mathrm{CH}_{3} \mathrm{Br}$ in the atmosphere. Thus seasonal variations should be minor, and perturbations due to El Niño conditions would be, at best, apparent only at the local or regional level. However, temperature and productivity variations large enough to impact the atmospheric budget have occurred in the past and are predicted to occur in the future due to anthropogenic global warming. These effects should be considered during the formulation of $\mathrm{CH}_{3} \mathrm{Br}$ regulatory policies.

A large area of uncertainty in modeling the natural geochemical cycle of $\mathrm{CH}_{3} \mathrm{Br}$ is the variability of the marine production rate. We suggest that one means of quantifying this term is to compare the $\mathrm{CH}_{3} \mathrm{Br}$ abundances predicted by models such as ours with in situ or satellite-based chlorophyll data. Our simple modeling of $\mathrm{CH}_{3} \mathrm{Br}$ in the eastern Pacific is a first step in this direction. Further progress requires more measurements of $\mathrm{CH}_{3} \mathrm{Br}$, temperature and primary productivity in the oceans, with wide geographic and seasonal coverage. Satellite estimates of chlorophyll concentration from the upcoming SeaWiFS experiment [SeaWiFS Working Group, 1987] will be particularly useful. These observations will be incorporated into three-dimensional extensions of our model, which will include the effects of horizontal transport in the ocean and atmosphere, as well as seasonal and climatic effects on atmospheric chemistry, to improve our understanding of the role of $\mathrm{CH}_{3} \mathrm{Br}$ in stratospheric $\mathrm{O}_{3}$ loss.

Acknowledgments. The authors are grateful to J. Butler and J. Lobert for providing $\mathrm{CH}_{3} \mathrm{Br}$ and temperature data in electronic format, and for many helpful comments. Thanks to G. Feldman and S. Pazen for providing CZCS data and Pacific oceanographic data, respectively, in electronic format. D. Halpern's suggestions in the early stages of this project are appreciated, as are those of A. Meinrat and an anonymous reviewer. This research was supported by NASA grant NAGW-413 and NOAA grant NA46GP0069. Division of Geological Sciences, California Institute of Technology, contribution 5539.

\section{References}

Albritton, D. L., and R. T. Watson, Methyl bromide and the ozone layer: A summary of current understanding, in Methyl Bromide: Its Atmospheric Science, Technology and Economics, Montreal Protocol Assessment Supplement, edited by R. T. Watson, D. L. Albritton, S. O. Anderson and S. Lee-Bapty, pp. 3-18, United Nations Environ. Prog., Nairobi, Kenya, 1992.

Anderson, J. G., W. H. Brune, S. A. Lloyd, D. W. Toohey, S. P. Sander, W. L. Starr, M. Loewenstein, and J. R. Podolske, Kinetics of $\mathrm{O}_{3}$ destruction by $\mathrm{ClO}$ and $\mathrm{BrO}$ within the Antarctic
vortex-An analysis based on insitu ER-2 data, J. Geophys. Res., 94, 11,480-11,520, 1989.

Atlas, E., W. Pollock, J. Greenberg, and L. Heidt, Alkyl nitrates, nonmethane hydrocarbons, and halocarbon gases over the equatorial Pacific ocean during Saga 3,J. Geophys. Res., 98, 16,933-16,947, 1993.

Balch, W., R. Evans, J. Brown, G. Feldman, C. McClain, and W. Esias, The remote sensing of ocean primary productivity: Use of a new data set compilation to test satellite algorithms, $J$. Geophys. Res., 97, 2279-2293, 1992.

Barber, R. T., and F. P. Chavez, Biological consequences of El Niño, Science, 222, 1203-1210, 1983.

Bathgate, R. H., and E. A. Moelwyn-Hughes, The kinetics of certain ionic exchange reactions of the four methyl halides in aqueous solution, J. Chem. Soc., 2642-2648, 1959.

Bretherton, F. P., K. Bryan, and J. D. Woods, Time-dependent greenhouse-gas-induced climate change, in Climate Change: The IPCC Scientific Assessment, edited by J. T. Houghton, G. J. Jenkins, and J. J. Ephraums, pp. 173-194, Cambridge University Press, New York, 1990.

Butler, J. H., The potential role of the ocean in regulating atmospheric $\mathrm{CH}_{3} \mathrm{Br}$, Geophys. Res. Lett., 21, 185-188, 1994.

Butler, J. H., Methyl bromide under scrutiny, Nature, 376, 469-470, 1995.

Butler, J. H., J. W. Elkins, T. M. Thompson, and B. D. Hall, Oceanic consumption of $\mathrm{CH}_{3} \mathrm{CCl}_{3}$ : Implications for tropospheric $\mathrm{OH}, J$. Geophys. Res., 96, 22,347-22,355, 1991.

Cane, M. A., Oceanographic events during El Niño, Science, 222, 1189-1210, 1983

Chavez, F. P., A comparison of satellite and ship chlorophyll from California and Peru, J. Geophys. Res., 100, 24,855-24,862, 1995.

Cicerone, R. J., L. E. Heidt, and W. H. Pollock, Measurements of atmospheric methyl bromide and bromoform, J. Geophys. Res., 93, 3745-3749, 1988.

Comiso, J. C., C. R. McClain, C. W. Sullivan, J. P. Ryan, and C. L. Leonard, Coastal Zone Color Scanner pigment concentrations in the Southern Ocean and relationships to geophysical surface features, J. Geophys. Res., 98, 2419-2451, 1993.

Elliott, S., and F. S. Rowland, Nucleophilic substitution rates and solubilities for methyl halides in seawater, Geophys. Res. Lett., 20, 1043-1046, 1993.

Eppley, R. W., Temperature and phytoplankton growth in the sea, Fish. Bull., 70, 1063-1085, 1972.

Falkowski, P. G., Y. Kim, Z. Kolber, C. Wilson, C. Wirick, and R. Cess, Natural versus anthropogenic factors affecting low-level cloud albedo over the North Atlantic, Science, 256, 1311-1313, 1992.

Feldman, G. C., Ocean color: Availability of the global data set, Eos Trans. $A G U, 70,634-636,1989$.

Folland, C. K., T. Karl, and K. Y. Vinnikov, Observed climate variations and change, in Climate Change: The IPCC Scientific Assessment, edited by J. T. Houghton, G. J. Jenkins and J. J. Ephraums, pp. 195-239, Cambridge University Press, New York, 1990.

Gingele, F., and A. Dahmke, Discrete barite particles and barium as tracers of paleoproductivity in South Atlantic sediments, Paleoceanography, 9, 151-168, 1994.

Gschwend, P. M., J. K. MacFarlane, and K. A. Newman, Volatile halogenated organics released to seawater from temperate marine macroalgae, Science, 227, 1033-1035, 1985.

Halpern, D., and G. C. Feldman, Annual and interannual variations of phytoplankton pigment concentration and upwelling along the Pacific equator, J. Geophys. Res., 99, 7347-7354, 1994.

Herguera, J. C., and W. H. Berger, Paleoproductivity from benthic foraminifera abundance: Glacial to postglacial change in the west-equatorial Pacific, Geology, 19, 1173-1176, 1991.

Itoh, N., and M. Shinya, Seasonal evolution of bromomethanes from coralline algae (Corallinaceae) and its effect on atmospheric ozone, Mar. Chem., 45, 95-103, 1994.

Keller, A. A., Modeling the effects of temperature, light, and nutrients on primary productivity: An empirical and a mechanistic approach compared, Limnol. Oceanogr., 34, 82-95, 1989. 
Keller, M. D., Dimethylsulfide production and marine phytoplankton: The importance of species composition and cell size, Biol. Oceanogr., 6, 375-382, 1991.

Khalil, M. A. K., R. A. Rasmussen, and R. Gundawardena, Atmospheric methyl bromide: Trends and global mass balance, $J$. Geophys. Res., 98, 2887-2896, 1993.

Lal, S., R. Borchers, P. Fabian, P. K. Patra, and B. H. Subbaraya, Vertical distribution of methyl bromide over Hyderabad, India, Tellus, 46B, 373-377, 1994.

Leaitch, W. R., L. A. Barrie, J. W. Bottenheim, S. M. Li, P. B. Shepson, K. Muthuramu, and Y. Yokouchi, Airborne observations related to ozone depletion at polar sunrise, $J$. Geophys. Res., 99, 25,499-25,517, 1994.

Li, S. M., Y. Yokouchi, L. A. Barrie, K. Muthuramu, P. B. Shepson, J. W. Bottenheim, W. T. Sturges, and S. Landsberger, Organic and inorganic bromine compounds and their composition in the arctic troposphere during polar sunrise, J. Geophys. Res., 99, 25,415-25,428, 1994.

Liss, P. S., and P. G. Slater, Flux of gases across the air-sea interface, Nature, 247, 181-184, 1974

Lobert, J. M., J. H. Butler, S. A. Montzka, L. S. Geller, R. C. Myers, and J. W. Elkins, A net sink for atmospheric $\mathrm{CH}_{3} \mathrm{Br}$ in the East Pacific Ocean, Science, 267, 1002-1005, 1995.

Lorenzen, C. J., A method for the continuous measurement of in vivo chlorophyll concentration, Deep Sea Res., 13, 223-227, 1966.

Mabey, W., and T. Mill, Critical review of hydrolysis of organic compounds in water under environmental conditions, J. Phys. Chem. Ref. Data, 7, 383-415, 1978.

Malone, T. C., Phytoplankton photosynthesis and carbon-specific growth: Light-saturated rates in a nutrient-rich environment, Limnol. Oceanogr., 27, 226-235, 1982.

Manley, S. L., and M. N. Dastoor, Methyl halide $\left(\mathrm{CH}_{3} X\right)$ production from the giant kelp, Macrocystis, and estimates of global $\mathrm{CH}_{3} \mathrm{X}$ production by kelp, Limnol. Oceanogr., 32, 709-715, 1986.

Manö, S., and M. O. Andreae, Emission of methyl bromide from biomass buming, Science, 263, 1255-1257, 1994.

McElroy, M. B., R. J. Salawitch, S. C. Wofsy, and J. A. Logan, Reductions of Antarctic ozone due to synergistic interactions of chlorine and bromine, Nature, 321, 759-762, 1986.

Mellouki, A., R. K. Talukdar, A.-M. Schmoltner, T. Gierczak, M. J. Mills, S. Solomon, and A. R. Ravishankara, Atmospheric lifetimes and ozone depletion potentials of methyl bromide $\left(\mathrm{CH}_{3} \mathrm{Br}\right)$ and dibromomethane $\left(\mathrm{CH}_{3} \mathrm{Br}_{2}\right)$, Geophys. Res. Lett., 19 , 2059-2062, 1992.

Michaels, A. F., et. al., Seasonal patterns of ocean biogeochemistry at the U.S. JGOFS Bermuda Atlantic Time-series Study site, Deep Sea Res. Part I, 41, 1013-1038, 1994.

Moelwyn-Hughes, E. A., The hydrolysis of the methyl halides, Proc. R. Soc. London A, 164, 295-306, 1938.

Moelwyn-Hughes, E. A., The kinetics of hydrolysis, Proc. R. Soc. London A, 220, 386-396, 1953.

Montzka, S., J. H. Butler, J.W. Elkins, S. Yuen, A. Clarke, J. Lobert, and L. Lock, Difficulties associated with measuring atmospheric levels of methyl bromide and other methyl halides, Eos Trans. $A G U, 76(17), \mathrm{S} 160,1995$.

Moore, R. M., M. Scarratt, and Z. Hu, Methyl chloride and bromide production by marine phytoplankton, Eos Trans. $A G U, 76(17)$ S161, 1995.

Moore, R. M., and R. Tokarczyk, Volatile biogenic halocarbons in the northwest Atlantic, Global Biogeochem. Cycles, 7, 195-210, 1993.

Morel, A., and J.-F. Berthon, Surface pigments, algal biomass profiles, and potential production of the euphotic layer: Relationships reinvestigated in view of remote-sensing applications, Limnol. Oceanogr., 34, 1545-1562, 1989.
Penkett, S. A., B. M. R. Jones, M. J. Rycroft, and D. A. Simmons, An interhemispheric comparison of the concentrations of bromine compounds in the atmosphere, Nature, 318, 550-553, 1985.

Philander, S. G., El Niño, La Niña, and the Southern Oscillation, pp. 1-293, Academic, San Diego, Calif., 1990.

Reeves, C. E., and S. A. Penkett, An estimate of the anthropogenic contribution to atmospheric methyl bromide, Geophys. Res. Lett., 20, 1563-566, 1993.

Salawitch, R. J., S. C. Wofsy, and M. B. McElroy, Chemistry of $\mathrm{OClO}$ in the Antarctic stratosphere: Implications for bromine, Planet. Space Sci., 36, 213-224, 1988.

Scarratt, M. G., and R. M. Moore, Production of methyl halides by axenic cultures of the marine diatom Phaeodactylum tricornutum, Eos Trans. $A G U, 76(17)$, S169, 1995.

Schauffler, S. M., L. E. Heidt, W. H. Pollock, T. M. Gilpin, J. F. Vedder, S. Solomon, R. A. Lueb, and E. L. Atlas, Measurements of halogenated organic-compounds near the tropical tropopause, Geophys. Res. Lett., 20, 2567-2570, 1993.

SeaWiFS Working Group, Secondary SeaWiFS Working Group, Rep.EOSAT:NASA SeaWiFS working group, NASA Earth Observ. Satell. Co., NASA Earth Sci. and Applic. Div., Washington, D. C., 1987.

Singh, H. B., and M. Kanakidou, An investigation of the atmospheric sources and sinks of methyl bromide, Geophys. Res. Lett., 20, 133-136, 1993.

Singh, H. B., L. B. Salas, and R. E. Stiles, Methyl halides in and over the eastern Pacific $\left(40^{\circ} \mathrm{N}-32^{\circ} \mathrm{S}\right)$, J. Geophys. Res., 88, 3684$3690,1983$.

Solomon, S., M. Mills, L. E. Heidt, W. H. Pollock, and A. F. Tuck, On the evaluation of ozone depletion potentials, $J$. Geophys. Res., 97, 825-842, 1992.

Sverdrup, H. U., M. W. Johnson, and R. H. Fleming, The Oceans, Prentice Hall, Englewood Cliffs, N. J., 1942.

Tokarczyk, R., and R. M. Moore, Production of volatile organohalogens by phytoplankton cultures, Geophys. Res. Lett., 21, 285-288, 1994.

Wennberg, P. O., et. al., Removal of stratospheric $\mathrm{O}_{3}$ by Radicals: Insitu measurements of $\mathrm{OH}, \mathrm{HO}_{2}, \mathrm{NO}, \mathrm{NO}_{2}, \mathrm{ClO}$, and $\mathrm{BrO}$, Science, 266, 398-404, 1994.

Wofsy, S. C., M. B. McElroy, and Y. L. Yung, The chemistry of atmospheric bromine, Geophys. Res. Lett., 2, 215-218, 1975.

World Meteorological Organization (WMO), Scientific assessment of ozone depletion: 1991, in World Meteorological Organization Global Ozone Research and Monitoring Project, vol. 25, 1992.

Yung, Y. L., J. P. Pinto, R. L. Watson, and S. P. Sander, Atmospheric bromine and ozone perturbations in the lower stratosphere, J. Atmos. Sci., 37, 339-353, 1980.

Zafiriou, O. C., Reaction of methyl halides with seawater and marine aerosols, J. Mar. Res., 33, 75-81, 1975.

A.D. Anbar, Department of Earth and Environmental Science and Department of Chemistry, University of Rochester, Rochester, NY 14627.

F.P. Chavez, Monterey Bay Aquarium Research Institute, Moss Landing, CA 95039.

Y.L. Yung, Division of Geological and Planetary Sciences, California Institute of Technology, Pasadena, CA 91125.

(Received November 16, 1994; revised August 31, 1995; accepted September 5, 1995.) 